\title{
Sclerotinia Rot of Carrot An Example of Phenological Adaptation and Bicyclic Development by Sclerotinia sclerotiorum
}

Sclerotinia rot of carrot (SRC), caused by Sclerotinia sclerotiorum (Lib.) de Bary, is among the most economically important diseases that threaten carrot production in many regions of the world (84). For over four decades, research on the management of this disease has been directed at various approaches, and yet currently available methods have not provided effective control in commercial crops. An important constraint in the development of practices to manage SRC has been the limited knowledge of the etiology and epidemiology of the disease. Epidemiological studies of diseases caused by $S$. sclerotiorum have been conducted for several hosts, including beans (Phaseolus vulgaris) (16), soybeans (Glycine max) (18), and rapeseed (Brassica campestris, B. rapa) (102). However, the epidemiology of SRC is not as well characterized and has at least two unique features associated with the biology of carrot and the adaptation of S. sclerotiorum to carrot development.

First, carrot is a biennial plant, and in carrot crops grown for root production, flowers are absent. The presence of senescing flower tissue such as petals is a prerequisite for infection in many crops because ascospores of $S$. sclerotiorum require a period of saprophytic growth before being able to infect healthy plant tissues. In carrots, the nutrient source during this critical period for $S$. sclerotiorum appears to be provided by senescing leaves and petioles. Thus, the presence of senescing leaves in the canopy would represent a susceptible stage in carrot phenology, and production of primary inoculum to coincide with this stage may constitute an important adaptation of S. sclerotiorum to carrots.

Secondly, SRC can develop in two distinct and interconnected epidemics during the course of one crop, the preharvest epidemic occurring in the field and the post-

Corresponding author: G. J. Boland, Department of Environmental Biology, University of Guelph, Guelph, Ontario, Canada, N1G 2W1; E-mail: gboland@uoguelph.ca

Publication no. D-2003-0319-01F

(C) 2003 The American Phytopathological Society harvest epidemic occurring in storage. This is the result of successive preharvest and postharvest cycles of $S$. sclerotiorum development in carrot crops. Depending on the cultivation practices used, this bicyclic nature of SRC is of great economic significance; however, the etiological and epidemiological factors that determine the quantitative relationships between these two epidemics are poorly understood. Focusing future research on the investigation of these unique features of SRC may reveal important epidemiological characteristics that will facilitate disease prediction and improved management practices.

\section{Carrot Production}

Carrot (Daucus carota L., subsp. sativus (Hoffm.) Arcang.) has been cultivated for human use since the tenth century and is valued for its medicinal and health benefits, sweetness, flavor, and versatility. Presently, carrots are a commercially important crop that represents $1.4 \%$ of the total world root, tuber, and other vegetable production (10). The annual world production of carrots has increased by $133 \%$ during the past three decades, amounting to 19.4 million metric tons in 2000 (10). Carrots are produced in at least 108 countries throughout six continents (Table 1), and the five largest producers in the world are China (26\%), the United States (10\%), Russia $(8 \%)$, Poland $(5 \%)$, and the United Kingdom (4\%) (10). In Canada, carrot is the second most important vegetable crop (Fig. 1 ), and with an annual production of 0.28 million metric tons in 2000 , it contributed $1.4 \%$ to the global carrot production (10).

Originating in central Asia (91), carrot is a cool-season vegetable that is cultivated primarily in temperate latitudes. However, the availability of cultivars adapted for cultivation in subtropical regions gives this crop a near worldwide distribution (118). Year-round availability of quality carrots is important for the continuous supply of fresh and processing markets. Therefore, effective extension of carrot availability beyond the normal harvest seasons through storage remains one of the primary challenges to producers, especially in temperate regions.
Storage methods and the period between harvest and marketing vary among regions (84). Primary long-term storage practices include indoor common storage that utilizes ventilated ambient air, and controlled temperature refrigeration. Carrots in these facilities are usually stored in piles or in wooden pallet boxes. Optimum indoor storage conditions consist of constant air temperatures 0 to $1^{\circ} \mathrm{C}$ and relative humidity (RH) 95 to $100 \%$ (120). These conditions are essential for minimizing moisture loss, preventing early senescence, and reducing microbial decay on stored carrots for up to 9 months (145). Superior storage conditions can be provided by ice-bank cooling systems that can deliver saturated air at a temperature near $0^{\circ} \mathrm{C}$ by supplying air-water counterflows through positive ventilation $(46,81)$. In regions where weather permits, in situ storage of carrots has been employed with varied success. In the UK and France for instance, carrots can overwinter in the ground covered with earth or polyethylene sheeting and straw, and harvested throughout the winter months $(46,118)$. A less practiced method is the placement of harvested roots in field clamps or trenches alternated with layers of sand or light textured earth (35).

\section{Sclerotinia Rot of Carrot}

Sclerotinia rot of carrot, also referred to as watery soft rot or cottony rot (5), was first reported on field carrots in Belgium by M. E. Coemans in 1860, while on stored carrots it was first described by $\mathrm{E}$. Rostrup in 1871 (103). Both authors claimed $S$. sclerotiorum as the parasite responsible for the rotting carrots, but it was Anton de Bary (1886) who finally confirmed the pathogenicity of this fungus to carrots. Since then, SRC has been reported in at least 20 carrot producing countries (Table 1) and has become important because of the sporadic and devastating nature of epidemics and the lack of effective control measures.

The disease affects both above- and belowground portions of the carrot plant. Carrots are particularly susceptible to $S$. sclerotiorum late in the growing season and during storage. Early in the growing 
season, the disease can occasionally cause damping-off of young seedlings. Later infections of the foliage can reduce yield by weakening the tops and rendering mechanical harvest inefficient. Disease occurrence has been associated with poorly drained areas, high plant densities, and vigorous crop canopies covering the ground (45). Symptoms on diseased roots are rarely evident at harvest. Occasionally, when conditions are favorable for rapid disease development, the entire foliar system may collapse and decay symptoms may be detectable on the crown. In Canada, 75 and $90 \%$ of crop damage attributed to SRC was recorded in individual fields in 1931 and 1934, respectively $(6,7)$.

The most extensive development of SRC occurs postharvest, and under these conditions disease can substantially affect marketable yield and shelf-life of carrot in storage, transit, and market. Estimates of yield losses in storage are scarce and often incomplete because they do not account for economic losses associated with premature sale of produce. In Canada, direct crop losses attributed to SRC in storage ranged from $30 \%$ in Manitoba (42) to $50 \%$ in Nova Scotia (9). In the United States, serious losses have also been recorded during carrot transportation (115) and storage (55).

\section{Symptoms of SRC}

Symptoms on foliage first appear as water-soaked, dark olive-green lesions associated with collapsed tissues (Fig. 2). Lesions expand rapidly over the entire leaf, petiole, and rosette with infected tissues soon becoming covered by abundant cottony, white mycelium (Fig. 3). Aerial hyphae usually appear about $10 \mathrm{~mm}$ behind the advancing discolored lesion (45). At an advanced stage of disease progress, affected tissues exhibit a bleached appearance, and occasionally an entire plant may collapse (Fig. 4). Eventually, large black sclerotia (2 to $20 \mathrm{~mm}$ ) form externally (Fig. 5), embedded in the mycelium or internally, within the pith of the petiole.

Typically, lesions on stored roots that are infected from the field develop in the crown region as localized softened tissue and white mycelial tufts erupting through the cuticle (Fig. 6). Mycelium from a single infected carrot can spread rapidly to adjacent roots, forming radiating pockets of infection (Fig. 7) with ramifying hyphae reaching up to $25 \mathrm{~cm}$ from the source (45). Lesions caused by this secondary spread of the pathogen can occur anywhere on the root and initially appear as water-soaked circular spots characterized by a slight discoloration of the infected tissue. At a later stage, the expanding lesions develop into a soft, watery, odorless rot, characterized by darkening of the invaded tissue and the presence of a rapidly spreading white mycelium. Colonized carrots are usually held together in large clumps by the extensive mycelial growth. The formation of individual large sclerotia on infected areas (Fig. 6) is a distinctive feature that differentiates SRC from other storage rots such as gray mold rot (Botrytis cinerea Pers.:Fr.), crater rot (Rhizoctonia carotae
Rader), and bacterial soft rot (Erwinia spp.). In addition, secondary organisms may gain entrance into infected areas and contribute to further disintegration of macerated tissue and the complete collapse of infected roots.

\section{Sclerotinia sclerotiorum}

$S$. sclerotiorum, the causal agent of $\mathrm{SRC}$, is an ubiquitous necrotrophic soilborne fungus that is among the most nonspecific of plant pathogens (114). S. sclerotiorum has a wide host range consisting of 408 species of herbaceous plants of diverse phylogenetic backgrounds, including 278 genera and 75 families (19). In addition to losses of yield and reduction of quality in a range of economically important crops, epidemics caused by this pathogen can lead to elimination of viable crop production and abandonment of fields to less profitable nonhost crops $(24,114)$. $S$. sclerotiorum is distributed worldwide, but it is more common in temperate and sub-

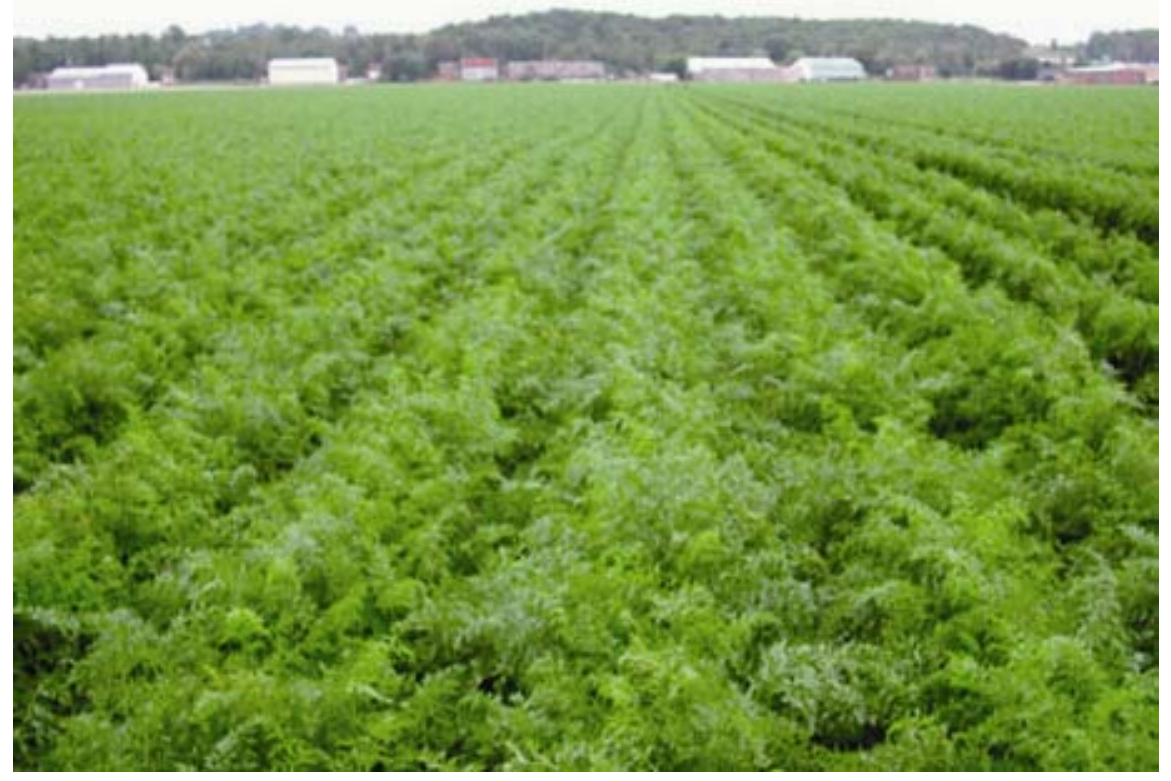

Fig. 1. A typical carrot field in organic soils of Bradford Marsh in Ontario, Canada.

Table 1. World production of carrots in 2000 and regional distribution of some countries where carrot crop losses attributed to Sclerotinia rot, caused by Sclerotinia sclerotiorum, have been reported

\begin{tabular}{|c|c|c|c|c|}
\hline Geographic region & $\begin{array}{c}\text { Harvested area } \\
\left(\text { ha } \times 10^{3}\right)\end{array}$ & $\begin{array}{c}\text { Yield }^{\mathrm{a}} \\
\left(\mathrm{kg} / \mathrm{ha} \times \mathbf{1 0}^{\mathbf{3}}\right) \\
\end{array}$ & $\begin{array}{c}\text { Production }^{\mathrm{a}} \\
\left(\mathrm{t}^{\mathrm{b}} \times \mathbf{1 0}^{\mathbf{3}}\right)\end{array}$ & Countries and reference \\
\hline World & 899 & 21.55 & 19,374 & \\
\hline Africa & 72 & 12.49 & 893 & Egypt (39) \\
\hline North and Central America & 79 & 33.25 & 2,627 & USA (115), Canada (48), Bermuda (147) \\
\hline South America & 46 & 22.65 & 1,034 & Brazil (90) \\
\hline Asia & 407 & 18.42 & 7,509 & India (117); Israel (107) \\
\hline Europe & 286 & 24.34 & 6,974 & $\begin{array}{l}\text { Austria (13); Finland (103); France (81); } \\
\text { Italy (24); Netherlands (33); Norway (12); } \\
\text { Poland (78); Romania (123); Russia (35); } \\
\text { Sweden (105); UK (46) }\end{array}$ \\
\hline Oceania & 9 & 39.45 & 337 & Australia (8); New Zealand (134) \\
\hline
\end{tabular}

a Source: 2000 FAO Production Yearbook, Vol. 54, FAO, Rome, 2001.

b Metric tons. 
tropical regions possessing cool and wet seasons $(114,150)$.

Establishment and spread of S. sclerotiorum among fields and geographic areas is achieved by several mechanisms and disseminative propagules. Wind dispersal of airborne ascospores and transportation of sclerotia through farming operations including tillage, irrigation, and manure fertilization are important means for longdistance distribution of the pathogen. Sclerotia formed on diseased plant tissue may be dislodged and persist in soil for several years $(3,29)$. Sclerotia-contaminated seeds and seeds infected with mycelium are also potential forms of pathogen introduction $(3,121)$.
S. sclerotiorum is classified within the genus Sclerotinia of the Sclerotiniaceae, an important family of Discomycetes of the Class Ascomycetes. The nomenclature of $S$. sclerotiorum has undergone several revisions since the species was first described by M. A. Libert as Peziza sclerotiorum in 1837. The taxonomy of the Sclerotiniaceae has been a source of controversy for years and continues to be under investigation. However, the taxonomic position of the genus Sclerotinia in Sclerotiniaceae and characterization of $S$. sclerotiorum as a distinct species of genus Sclerotinia are substantiated by several lines of evidence, including genetic markers and nucleotide sequence homologies $(58,74,76)$.

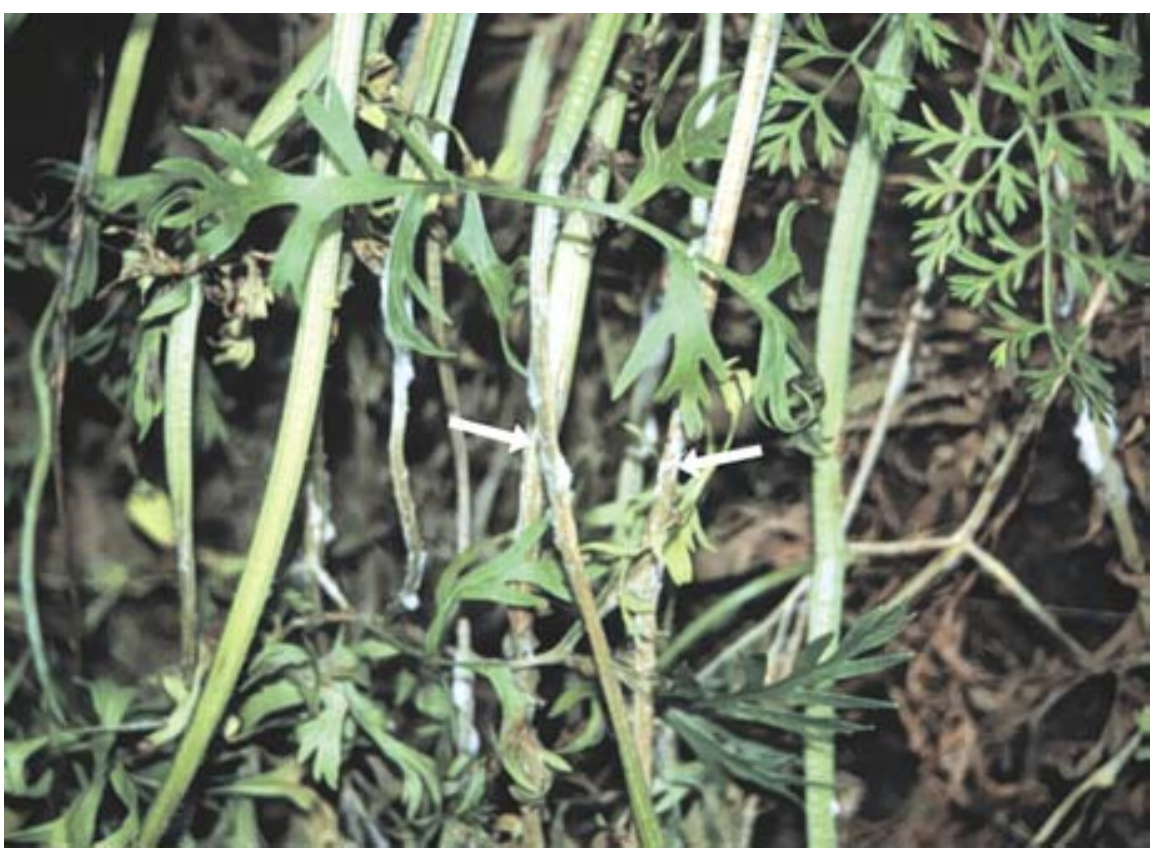

Fig. 2. Carrot leaves and petioles showing symptoms of Sclerotinia rot.

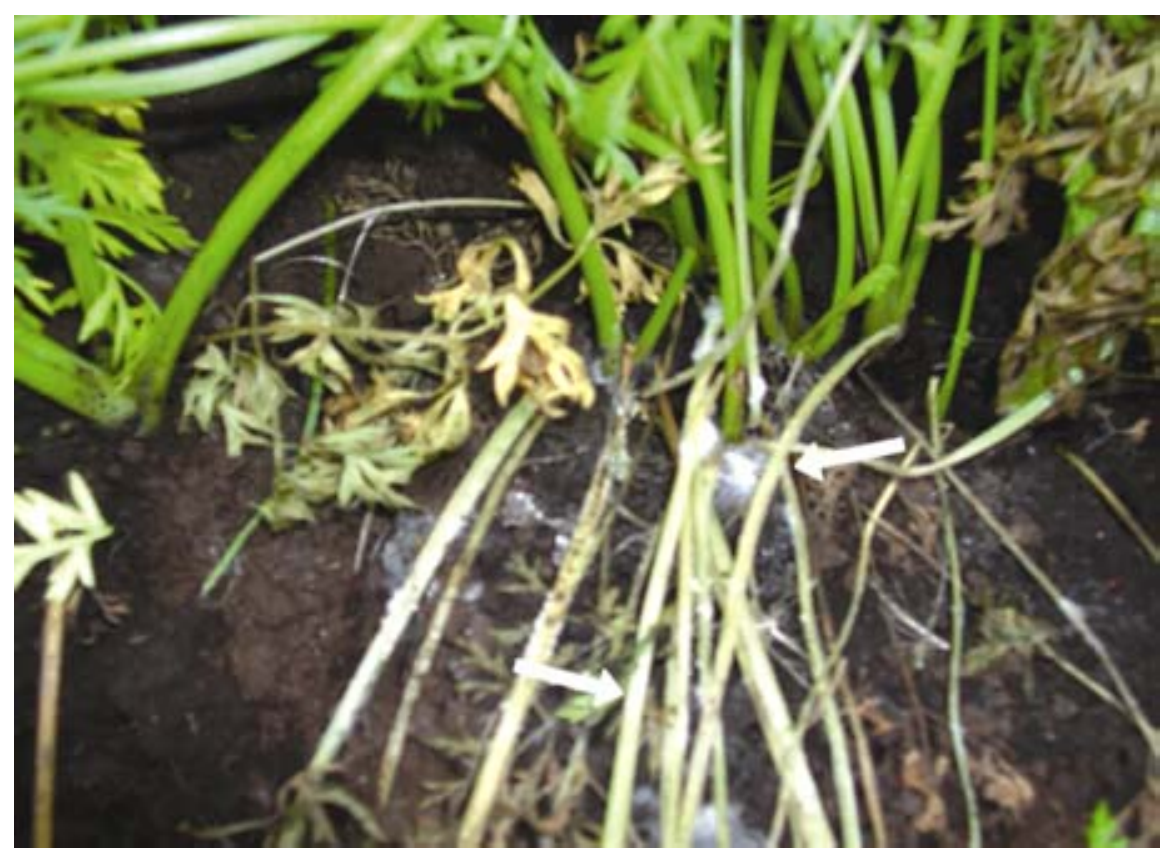

Fig. 3. Lesions of Sclerotinia rot advancing on carrot petioles and the rosette.

World populations of $S$. sclerotiorum are composed of genetically heterogeneous subpopulations $(23,75,77)$ that may be associated with phenotypic variability such as fecundity (31) and aggressiveness (79). Mycelial compatibility grouping and DNA fingerprinting have indicated that field populations of the fungus are characterized by a predominantly clonal structure with many unique genotypes geographically distributed over long distances $(32,73)$. As a homothallic organism, S. sclerotiorum reproduces sexually by self-fertilization, resulting in the formation of apothecia and airborne ascospores, and asexually by formation of sclerotia. These reproductive modes contribute to the preservation of successful genotypes, but provide limited genetic variability. Most intraspecific genetic variations in S. sclerotiorum arise from mutation. However, genetic exchange and recombinations also account for some new genotypes $(32,72)$, presumably with individual clonal genotypes becoming epidemiologically prevalent within each population.

\section{Etiology of SRC}

During its life cycle, S. sclerotiorum progresses through three stages of development that include dormancy, saprophytism, and parasitism. From a management perspective, during sclerotial dormancy the pathogen is least accessible to most control methods. In contrast, the pathogen is more vulnerable during mycelial and carpogenic germination because of poor competitive saprophytic ability and high dependence on environmental factors, respectively. However, there are two key adaptation strategies during this saprophytic stage that contribute to the success of $S$. sclerotiorum in establishing a parasitic relationship with carrots. First is the ability of the fungus to continue producing sclerotia on diseased foliar debris after being detached from the living carrot plant, thus increasing the amount of inoculum in soil. Second is its ability to attune to carrot crop phenology, i.e., to develop apothecia and ascospores in synchrony with the susceptible stage of carrot. The pathogen may become less vulnerable to environmental stresses or control methods during parasitism, when it is established in the carrot plant. Adverse conditions occurring during these growth stages may affect the overall development of the fungus. Therefore, knowledge of variations in the biological characteristics of S. sclerotiorum in relation to carrot development and the physical environment within carrot crops is important in designing management practices that aim at interrupting the life cycle of the pathogen.

\section{Dormancy}

S. sclerotiorum spends about $90 \%$ of its life cycle in soil as dormant sclerotia which develop primarily from mycelia on diseased tissues (3). Mature sclerotia can 
survive in soil for 1 to 5 years, depending on the interaction of various physical and biological factors $(3,29)$. Physical factors in the soil environment, including prolonged periods of high temperatures, flooding, sequential drying and wetting (127), deep burial below the soil surface, and exposure to solar radiation, can reduce the viability of sclerotia (3). However, microbial degradation remains the most significant factor affecting populations of sclerotia in natural ecosystems (3). More than 30 species of fungi and bacteria have been identified as antagonists or mycoparasites of Sclerotinia species, but Coniothyrium minitans Campbell, Trichoderma spp., and Sporidesmium sclerotivorum Uecker, Ayers, \& Adams are likely responsible for the destruction of the majority of sclerotia in soil (3). Structural malformations or fractures in the melanized rind may also contribute to reduced longevity of sclerotia by increasing susceptibility to microbial degradation (28). In addition, soil mycophagous animals such as fungus gnats (Bradysia coprophila; Diptera: Sciaridae) and springtails (Folsomia candida; Collembola: Entomobryidae) can reduce populations by direct consumption of sclerotia, mycoparasite transmission, or predisposing damaged sclerotia to infection by mycoparasites $(11,52,149)$.

\section{Saprophytism}

Germination. During suitable environmental conditions, mature sclerotia can germinate myceliogenically to form mycelium or carpogenically to form apothecia (3). During myceliogenic germination, sclerotia produce masses of mycelia, which are capable of direct penetration of the host cuticle but require an exogenous nutrient source to be infective $(1,89)$. Mycelia originating from sclerotia of $S$. sclerotiorum possess limited competitive saprophytic ability and, in nonsterile soil, were unable to infect plants located more than 2 $\mathrm{cm}$ from the source $(104,151)$.

Carpogenic germination requires functionally mature and preconditioned sclerotia located in the upper 2- to 3-cm layer of soil (2). The dormancy period required before sclerotia can germinate carpogenically varies from 13 to 208 days depending on environmental and physiological factors (150). Conditioning requirements for carpogenic germination may depend on the geographic origin of isolates as this relates to the temperature at which sclerotia are formed (64). Typically, constitutive dormancy can be relieved by conditioning sclerotia for prolonged periods in cool, moist conditions, or by overwintering in soil (2). Carpogenic germination of sclerotia occurs at soil matric potentials ranging from 0 to -7.5 bars $(16,101,135)$. However, moisture levels -0.1 to -0.4 bars were most favorable for apothecial production (135), and saturated soils (0 bars) may suppress germination due to lack of aera- tion or rotting of sclerotia (101). Sclerotia can imbibe moisture up to amounts equivalent to their dry weight (30). In the laboratory, full hydration of sclerotia occurred within $4 \mathrm{~h}$ of immersion in water, while release of moisture from fully hydrated to fully desiccated sclerotia required up to 25 h. Moisture content of soil-buried sclerotia follows changes in the matric potential of the soil and can reach an equilibrium within $6 \mathrm{~h}$, but sclerotia can remain partially hydrated in extremely dry soils (30). Typically, in field conditions, development of apothecia is stimulated by extended periods (e.g., $>10$ days) of high soil moisture potentials ( 0 to -0.3 bars), cool ( 4 to $20^{\circ} \mathrm{C}$ ) soil temperatures, and a dense plant canopy over the soil $(2,53,102,121)$. Similarly, emergence of apothecia in carrot crops was associated with an enclosed canopy and prolonged rain or irrigation events (30).

Carpogenic germination leading to formation of phototropic stipes and development of mature apothecia is optimal in soil temperatures of 11 to $15^{\circ} \mathrm{C}$ (1). However, differentiation and full expansion of the apothecial disk and ascospore production

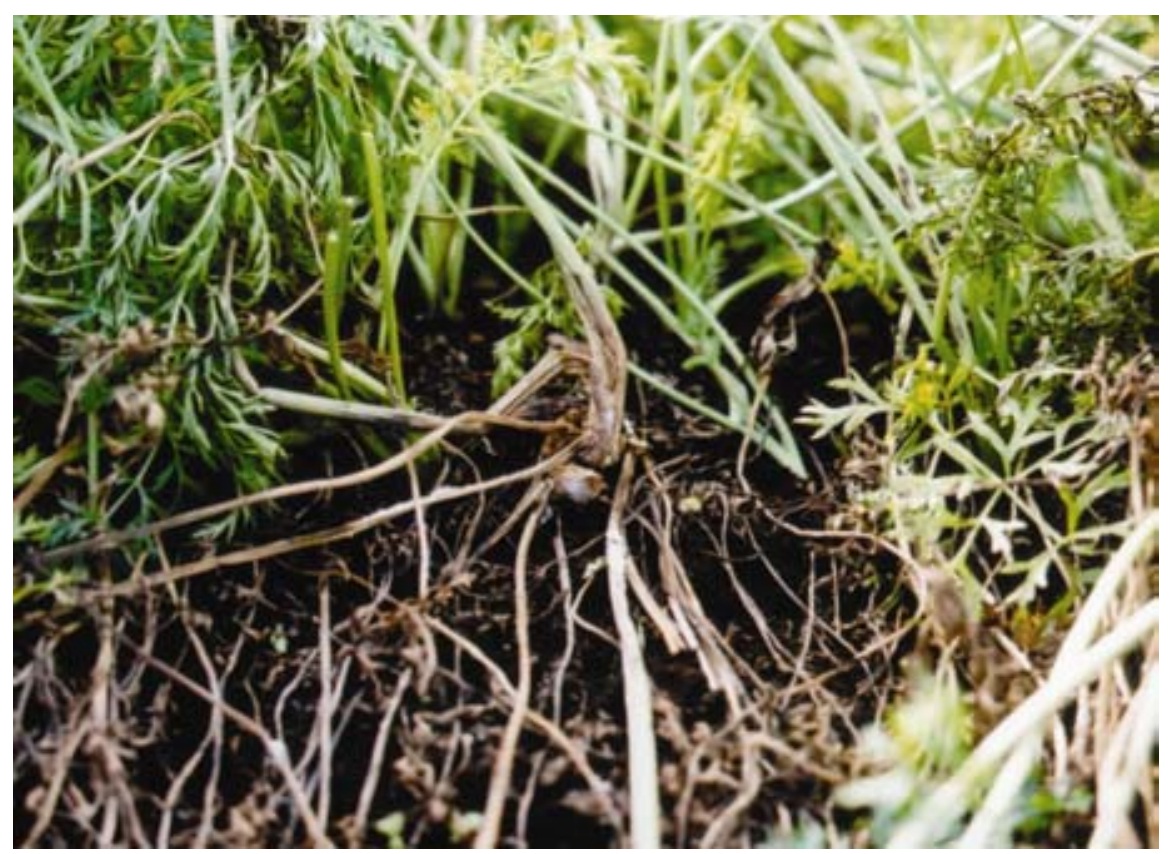

Fig. 4. Collapsed leaves and petioles of a carrot plant in the field due to severe infection by Sclerotinia sclerotiorum.

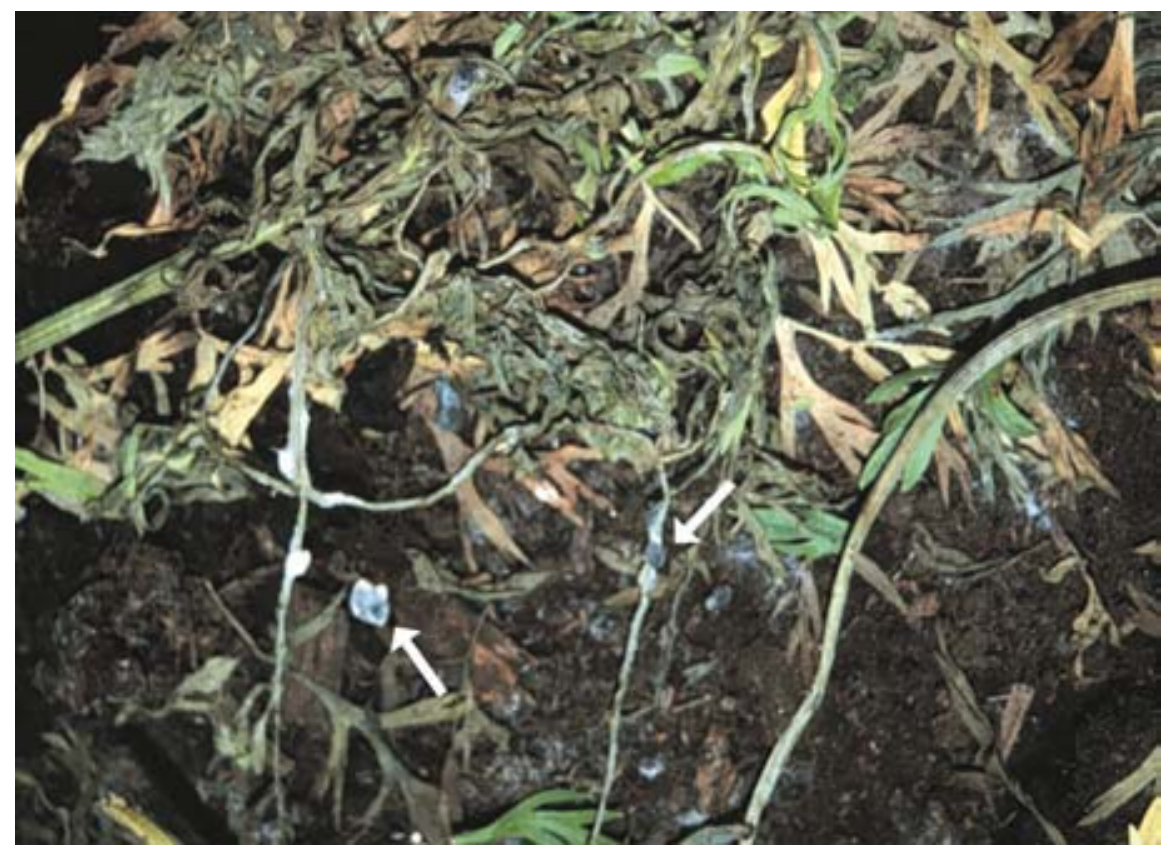

Fig. 5. Newly produced sclerotia of Sclerotinia sclerotiorum on diseased carrot leaves and soil surface. 
occur only in light and require wavelengths below $390 \mathrm{~nm}$ and temperatures 15 to $20^{\circ} \mathrm{C}(28,82,150)$. Mature ascospores are forcibly discharged to a distance of more than $1 \mathrm{~cm}$ above the upper surface of the apothecium when subjected to a decrease in moisture tension in the surrounding air (2). Apothecia can remain functional for 5 to 10 days in field conditions and can produce up to $3 \times 10^{7}$ ascospores $(121,129)$.

Aerobiology. Aerobiological studies of $S$. sclerotiorum in carrot crops are not available. Studies in other crops have revealed a diurnal distribution of ascospores characterized by consistent peaks of spore deposition occurring between 900 to 1300 $h$ in several geographic regions $(14,56,66)$. Conversely, seasonal patterns of ascospore distribution vary among geographic regions because of differences in climates and cropping seasons. Peaks of ascospore deposition have been recorded during January and February in Israel (14), March in New Zealand (56), July and August in Canada (153), or October and November in North Carolina, USA (66). Daily peaks in abundance of ascospores occurred after sunrise, perhaps in response to increased light intensity and decreased $\mathrm{RH}$, whereas seasonal peaks followed periods of high soil moisture (56). Aerial dispersal of ascospores can reach up to several kilometers (2), but most ascospores are deposited within $100(14,129)$ or $150 \mathrm{~m}(130)$ from the source. Ungerminated ascospores can survive for up to 12 days in the crop depending on their position in the canopy and environmental conditions. Ascospore mortality increases with increasing temperatures above $21^{\circ} \mathrm{C}$ and exposure to ultraviolet radiation (22).

Adaptation. Ascospores of S. sclerotiorum are not able to infect until an exter-

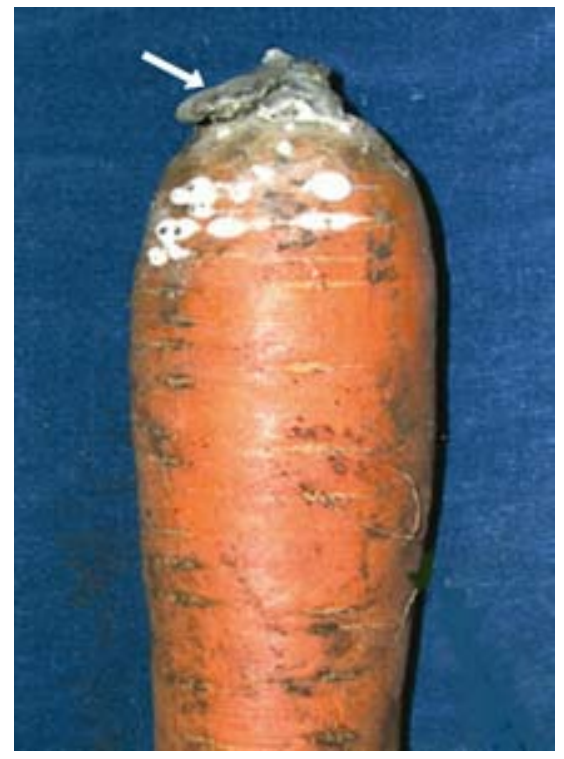

Fig. 6. Mycelium of Sclerotinia sclerotiorum erupting from the crown of a stored carrot originally infected in the field and a sclerotium formed on top of the root. nal source of nutrition, such as senescing plant tissues or dead blossoms, and free water are available (89). However, unlike initial petal infestation in flowering plants such as bean (2) and canola (95), in carrots, the exogenous food base for germinating ascospores is restricted to aged foliage. Carrot plants were not susceptible to foliarapplied ascospores of $S$. sclerotiorum unless older senescing leaf tissue was present in the canopy (45). Increased susceptibility of senescing leaves was associated with higher incidence of appressoria formation and failure to react hypersensitively to the penetration of S. sclerotiorum. In the field, carrot crops were particularly susceptible to $S$. sclerotiorum when senescing foliage was lodged on the soil surface (45). This probably occurs because upright senescing leaves are subjected to continuous fluctuations and interruptions of leaf wetness periods due to wind and sunlight. Lodged senescing leaves can have longer wetness periods due to their contact with moist soil and humid conditions under the dense canopy cover, thus providing more favorable conditions for infection to occur. Therefore, the onset of lodged senescing leaves appears to be an important event in determining the susceptible stage of carrot crops to infection by S. sclerotiorum. Once started, foliar senescence of carrots progresses concurrently with the development of new leaves, and accumulation of senescing foliage on soil continues until harvest.

The pattern of foliar senescence, differential susceptibility of carrot leaves in relation to their age, and position of older leaves within the canopy appear to be important for the development of SRC. However, little information is available regarding the phenological development of carrot that describes the timing, rate, and patterns of foliar senescence or canopy lodging. For example, initial appearance of senescing leaves in carrots crops in UK occurred after 84 days of plant growth (45). In carrot crops grown in organic soils of Bradford Marsh, Ontario, the onset of lodged senescing leaves ranged from 54 to 89 days after planting when carrots were between sixth and tenth leaf stage (C. Kora, unpublished). Patterns of foliar senescence may vary with carrot age, cultivar, plant density, nutrient and irrigation regime, soil type, or weather. In addition, stresses imposed by other foliar diseases of carrot such as leaf blights (Alternaria dauci (Kühn) Groves \& Skolko and Cercospora carotae (Pass.) Solheim) may encourage senescence and lodging.

The presence of apothecia and ascospores during this susceptible stage of carrot development has been observed $(30,45)$ and is probably the most critical factor in the initiation of SRC epidemics. Emergence of apothecia has been associated with the development of a full canopy cover in carrot (30) and several other crops $(16,18,102,121)$. An enclosed canopy can buffer the effect of fluctuating soil moisture and temperature at the soil-plant interface and create conditions that are conducive for the development of apothecia and survival of ascospores $(2,22,121,148)$. The appearance of lodged, senescing leaves in carrot crops usually occurs close to or after full canopy enclosure. Therefore, extended periods of concurrent production of inoculum and accumulation of susceptible tissue can cause widespread epidemics of SRC, particularly when favorable weather conditions prevail.

\section{Parasitism}

Histopathology. Germinating ascospores of S. sclerotiorum initiate infection

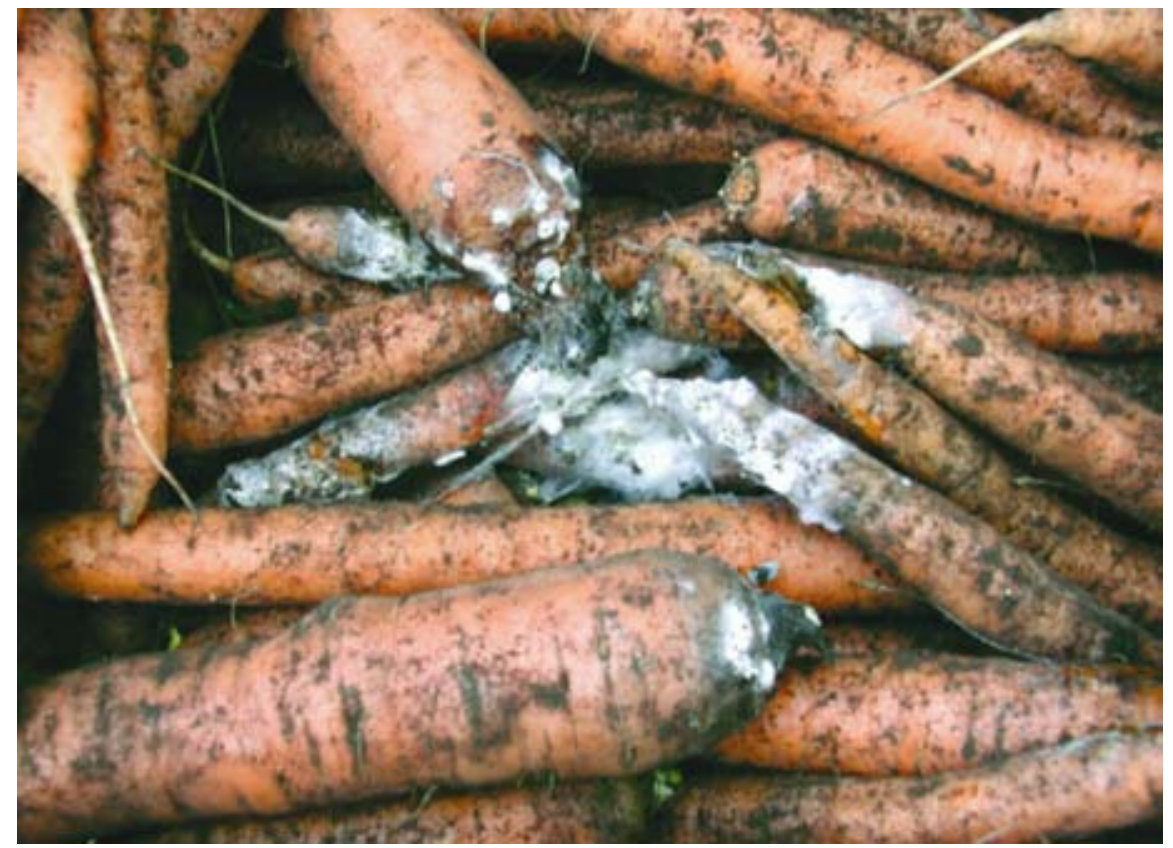

Fig. 7. Secondary spread of Sclerotinia rot among carrot roots in storage. 
through the production of simple, single appressoria that penetrate directly through the host cuticle. Infection can also occur through direct cuticle penetration by mycelia, which is achieved by complex, multicelled appressorial masses. Penetration is mainly attained by mechanical pressure aided by the activity of fungal enzymes involved in the modification of the cuticle $(89,133)$. After penetration, an inflated, granular vesicle develops that gives rise to infection hyphae. Mycelial growth progresses from these infective hyphae and rapidly colonizes host tissues by inter- and intracellular penetration. After extensive colonization of the interior tissues, ramifying hyphae emerge through the cuticle, forming mycelial tufts on the surface. Eventually, mature sclerotia form on diseased tissues and are released onto the soil along with plant debris (89).

Pathogenesis. S. sclerotiorum possesses a nonselective mechanism of attack that can successfully invade a host plant before it can respond. Pathogenesis by $S$. sclerotiorum is attributed to the secretion of oxalic acid $(25,49,92)$ and a series of cellwall-degrading and cell-membrane-modifying enzymes, including pectolases $(89,116)$, cellulases (87), hemicellulases (54), and phosphatidases (88) that degrade and kill carrot cells in advance of invading hyphae (89). Oxalic acid has been confirmed as an essential pathogenicity deter- minant in S. sclerotiorum (49) and appears to be involved in several modes of action that are activated upon successful entry of the pathogen into the host. Oxalate enhances the activity of lytic enzymes by reducing the $\mathrm{pH}$ of the infected tissue, weakens the plant cell by sequestering cell wall $\mathrm{Ca}^{2+}$, and suppresses host defense mechanisms by inhibiting polyphenol oxidases (92,93). Cessna et al. (25) proposed that oxalate may also suppress the oxidative burst of the host plant, which is the earliest resistance response of invaded tissue.

\section{Epidemiology}

The preharvest epidemic. Early workers postulated that primary infection of carrot was initiated by mycelium arising from myceliogenically germinating sclerotia in soil $(80,103)$ or by airborne ascospores of S. sclerotiorum (115). However, there was insufficient evidence on the epidemiological significance of these forms of inoculum in the field.

A study in Manitoba, Canada, demonstrated that infection of carrots was initiated primarily through mycelial colonization of leaf and stem tissues close to, or in direct contact with, germinating sclerotia located on or near the soil surface (42). In controlled experiments, foliar infection occurred more readily and disease in storage was greater when mycelial inoculum was placed near carrot foliage that was in contact with soil than when mycelium was placed near roots. Mycelium of $S$. sclerotiorum was capable of infecting carrot leaves even after advancing a distance of 0.5 to $1 \mathrm{~cm}$ through soilless growing medium. In contrast, foliarapplied ascospores required at least 11 days of continuous leaf wetness to produce disease in foliage and stored roots. In field conditions, inoculation with an ascospore suspension did not cause disease on foliage or stored roots, as leaf wetness duration was never sufficient for infection to occur (42). However, there was no indication in these studies of the role of differential susceptibility of leaf tissues to ascospores with respect to their developmental stage or position within the canopy.

Studies in the UK indicated that airborne ascospores produced in autumn were the most important inoculum in initiating epidemics of SRC in the field (45). The presence of apothecia within carrot crops has been consistently associated with the initial appearance of symptoms of SRC $(30,45)$. However, the absence of apothecia in some infected carrot crops (45) suggests the presence and relative importance of extrinsic sources of ascospores, as reported for epidemics of white mold in bean $(1,16)$, lettuce drop (109), and Sclerotinia stem rot in rapeseed (102). In optimum controlled conditions, treatment with airborne asco-

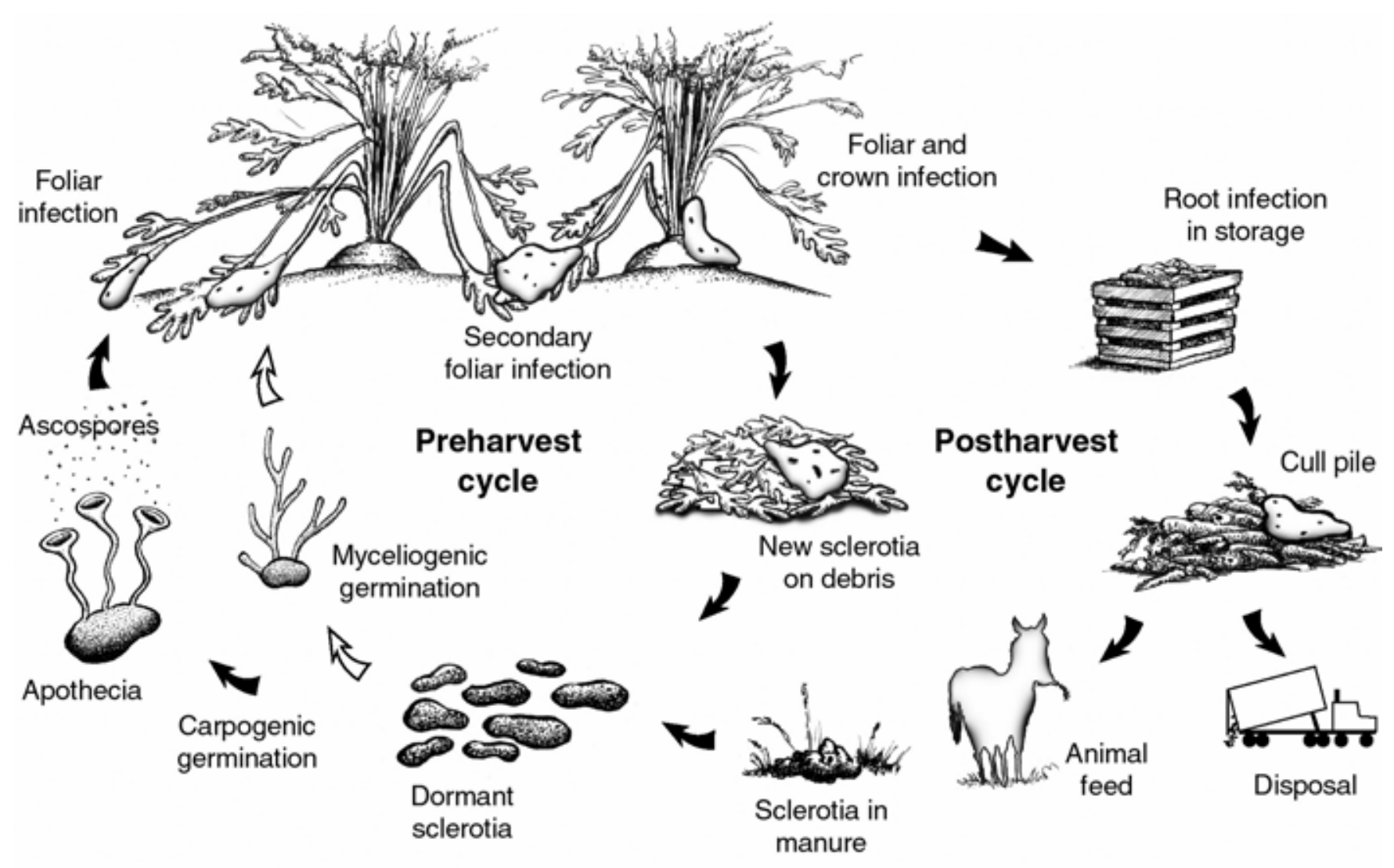

Fig. 8. Preharvest and postharvest disease cycles of Sclerotinia rot of carrot caused by Sclerotinia sclerotiorum in a cropping system typical for temperate regions. 
spores initiated foliar infection only when carrot plants were at the seven- to eightleaf stage or later and had at least one senescing leaf at the time of inoculation. Symptoms developed only on senescing leaves and appeared 3 to 4 days after inoculation. Infection spread to the crown and new sclerotia formed on the foliage about 14 days after inoculation (45).

These studies suggest that airborne ascospores and soilborne hyphae are important primary inocula for the epidemiology of SRC in the field (Fig. 8), and their prevalence may depend on the region, environmental conditions, and cropping systems. Although S. sclerotiorum is capable of infecting by hyphae or ascospores, it appears to function primarily by producing apothecia, and mycelial germination from sclerotia contributes minimally, if at all, to the development of epidemics (2). In other crops, S. sclerotiorum infects senescing plant tissues by means of ascospores $(1,27,62,102,109)$, and direct infection by sclerotia is not considered important except for the basal infection of sunflower (Helianthus annuus) (61) and tomato (Lycopersicon esculentum) (83), and infection of bean leaves in contact with the soil surface (140). Airborne ascospores are considered more effective in initiating widespread epidemics because of their long-range dispersal, higher inoculum potential, and relative persistence within the canopy. The widespread and sporadic nature of SRC epidemics also suggests that, in carrot crops, ascospores are more likely to be the most significant primary inoculum. However, there are several common attributes that characterize both modes of disease initiation regardless of the primary inoculum: (i) sclerotia located near the soil surface are the most important source of

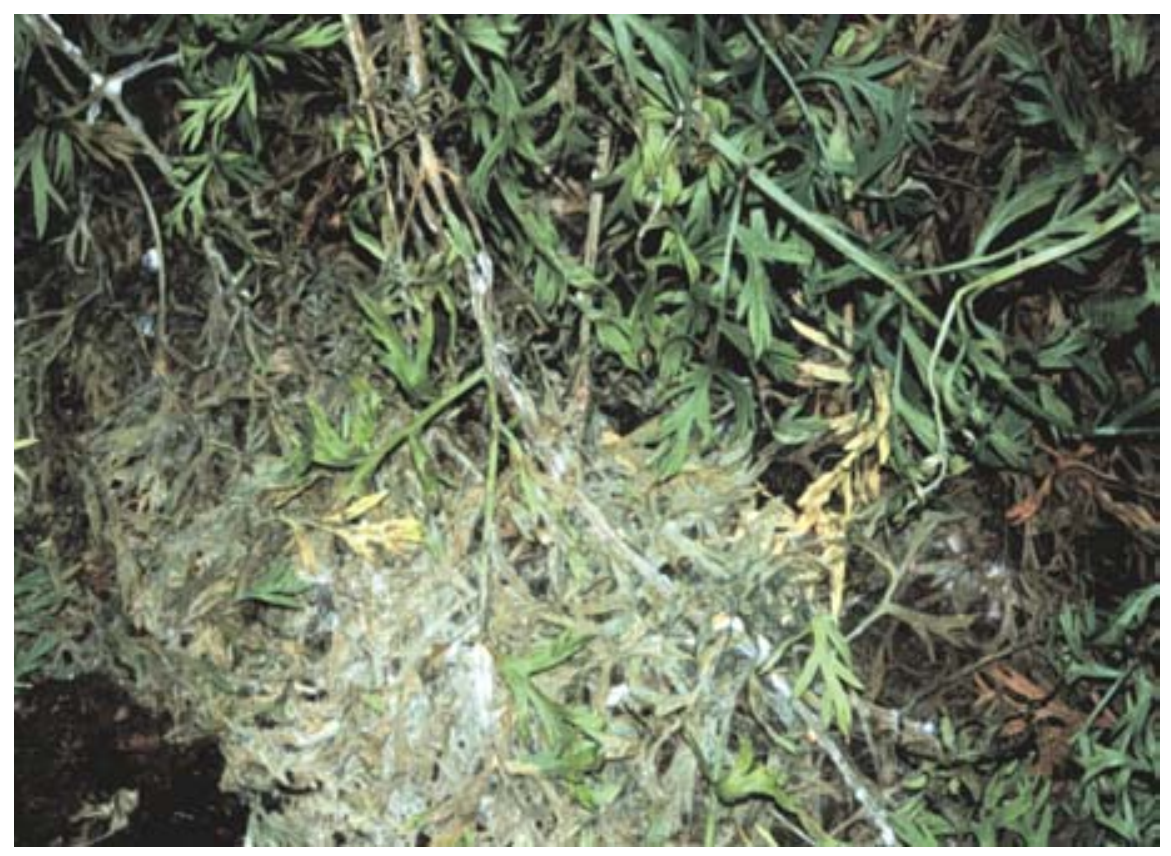

Fig. 9. Secondary spread of foliar Sclerotinia rot among carrot plants in the field.

inoculum for both infections; (ii) both inocula need free moisture and an exogenous nutrient source to be infective; (iii) both modes require the presence of older or senescing leaves lodged on the soil surface; and (iv) disease progress in both modes is encouraged by humid microclimate conditions within the enclosed canopy of mature carrot crops. These attributes are important considerations to address when attempting to design strategies for the management of SRC.

Regardless of the type of primary inoculum, root infection results from infected foliage and occurs via the crown $(42,45,84)$. Direct infection of carrot roots by mycelium arising from sclerotia in soil has not been observed, and root infection always occurs after the foliage and crown become infected. Mycelium arising from lesions on foliage can progress through the petiole toward the crown, from which it enters the root (42). Infection of carrot roots via petioles wounded by $S$. sclerotiorumcontaminated machinery during mechanical harvest may be an additional source of disease in storage (132). Following the crown pathway, mycelium can circumvent the periderm, which may be a structural barrier to penetration from the exterior of the root (44).

Optimum conditions for infection of carrots are prolonged periods of high moisture and temperatures of 13 to $18^{\circ} \mathrm{C}$ (118). Once infection is established, invaded tissue usually provides sufficient moisture for fungal growth and lesion expansion; however, prolonged dry conditions can suppress disease progress (45). Mycelium originating from diseased leaves can readily colonize adjacent senescing leaves, foliar debris lying on the soil surface, and healthy foliage of neighboring plants (Fig.

462 Plant Disease / Vol. 87 No. 5
9). This is encouraged by the high plant density that is typical in current carrot cultivation practices (Fig. 1). Therefore, secondary infection due to plant-to-plant contact may be an important means of local spread of the pathogen that increases disease incidence in carrot crops. The preharvest cycle of S. sclerotiorum development is completed with the return to soil of new sclerotia produced on diseased leaves. These sclerotia will eventually germinate to form apothecia (Fig. 10) or mycelium during subsequent seasons and initiate new epidemics of SRC.

The postharvest epidemic. Disease of carrots in storage or in transit is a direct consequence of foliar and crown infection in the field $(42,45,84)$, and every infected root has the potential to develop into a source of inoculum for new infections during storage (Fig. 8). However, incidence of foliar disease in the field may not qualify as a good indicator of initial root disease incidence or potential crop loss in storage, as no quantitative correlations between these cycles have been observed (45). The development of this secondary epidemic is a unique feature that characterizes SRC from many other Sclerotinia diseases, but it becomes important when harvested carrots are designated for storage or long-distance transportation. Infections in storage are initiated mainly by mycelium arising from the crowns of diseased roots introduced from the field (45). The colonized root can provide sufficient nutrient reserves for the fungus to spread rapidly toward adjacent roots $(45,103)$. The presence of wounded tissue caused by mechanical harvesting or handling can increase susceptibility of carrots and encourage secondary infection in storage, but is not essential (45). Mycelium of $S$. sclerotiorum persisting on the surface of infested wooden containers $(103,115,131)$ or in foliar debris adhering to the roots (45) may represent an additional source of contamination for carrots in storage.

Preharvest and postharvest epidemics of SRC differ in several biological and environmental characteristics. Compared to foliar substrates, carrot roots are storage organs with higher nutrient content that encourage more extensive fungal growth and abundant sclerotia production. Humidity within storage is usually sufficient to favor fungal growth, but low temperatures can substantially limit the development of SRC in storage. S. sclerotiorum can infect carrot roots in temperatures ranging from 0 to $28^{\circ} \mathrm{C}$, with maximum decay occurring at $23^{\circ} \mathrm{C}(80,103)$. Finally, excluding sclerotia returned to the field through manure fertilization, most new sclerotia produced on diseased roots in storage do not contribute to the increase of inoculum in soil and do not sustain the initiation of new epidemics. Thus, although economically important, this postharvest cycle in the development of S. sclerotiorum is epidemiologically incomplete. 


\section{Disease Management}

Consistent and economical management of most diseases caused by S. sclerotiorum, including SRC, has been difficult to achieve because of their widespread distribution, sporadic occurrence, and the longterm persistence of sclerotia in soil. In the past, most management strategies for these diseases have relied on cultural practices that reduce the frequency of sclerotia in soil and protective strategies that prevent infection of the crop, such as the use of fungicides and tolerant or resistant cultivars. However, chemical control is considered cost-effective only on selected highvalue crops, and cultural practices have had variable results (128). The lack of effective disease management practices and the potential risk of developing fungicide-resistant strains of the pathogen have stimulated further investigation of biological alternatives, host resistance, disease prediction, and microclimate modification.

Cultural control. Several cultural practices such as burial of crop refuse through deep (15 to $20 \mathrm{~cm}$ ) plowing (98), flooding (100), soil solarization (111), grass mulching (40), reduced irrigation frequencies (129), and weed management (34) can effectively reduce populations of sclerotia in soil, prevent their germination, or decrease disease in several crops. Crop rotation has also been advocated as a method to control diseases caused by $S$. sclerotiorum (128), but 3- and 4-year rotations with nonhost crops have not been effective in decreasing the frequency of sclerotia in soil $(121,152)$ or reducing Sclerotinia stem rot in rapeseed crops (102), respectively. Sanitation methods such as steam sterilization of soil for at least $10 \mathrm{~min}$ resulted in up to $85 \%$ mortality of sclerotia buried at 2 $\mathrm{cm}$ in the field (30). The efficacy of steam sterilization in these studies was positively related to the moisture content of the soil and sclerotia, and inversely related to the depth at which sclerotia were buried. Consequently, moistening the soil prior to steaming is critical because only fully and partially hydrated sclerotia are susceptible to steam sterilization, and dry sclerotia are more resistant to high temperatures (30). These cultural methods are often ineffective, especially when extrinsic sources of ascospores are important for initiating infections (129); therefore, integration with other management tools is needed for enhancing their efficacy.

Any product or cultural practice that affects the canopy architecture and phenology of a carrot crop could indirectly influence germination of sclerotia and subsequent SRC development. Adequate plant spacing and cultivation in raised beds can reduce soil moisture and enhance aeration within the canopy, thus providing some cultural modifications that improve disease control (118). Application of low rates of nitrogen, such as $6 \mathrm{~kg}$ a.i. (active ingredi- ent) $\mathrm{ha}^{-1}$, was associated with significant reduction of canopy size and density, less lodging, and lower levels of SRC compared with $60 \mathrm{~kg}$ a.i. $\mathrm{ha}^{-1}$, with negligible effect on yield (30). Excessive nitrogen inputs may delay foliar senescence in carrots; however, excess foliage growth encouraged by high rates of nitrogen can increase shading of lower leaves and accelerate their senescence. Therefore, balanced nitrogen applications that meet the crop needs based on soil type and fertility should be encouraged especially for fields with high disease risk. Modification of standard cultural practices that prevent infection by minimizing physical contact between foliage and soil (42) or by preventing the development of a full canopy and the accumulation of susceptible senescent foliage between the rows (45) have been suggested, but viable commercial systems to achieve these were not identified.

Preharvest cultural practices that influence postharvest quality of carrot are important for reducing the susceptibility of carrot to SRC during long-term storage. A balanced fertilization program that provides adequate potassium and avoids excess nitrogen can reduce postharvest moisture loss by maintaining root tissue integrity (125). Prevention of preharvest water stress may also increase membrane integrity of carrot roots and reduce moisture loss during storage (124). Supplemental foliar applications of calcium-containing products such as calcium nitrate, Calcimax, and Nova Cal were tested in the field from 1997 to 1999, but did not reduce the incidence of SRC in storage. Calcium nitrate was phytotoxic at concentrations higher than $0.1 \%$ and caused leaf burn (M. R. McDonald, unpublished). Timing of harvest may also affect the susceptibility of carrot to most storage rot diseases through the effect of carrot age, physiological state, and weather conditions before and during harvest. In Finland, for instance, reduced losses from SRC in storage were associated with relatively longer carrot growing periods, higher sucrose-glucose ratios in roots at harvest, and dry weather conditions during harvest (103).

Minimizing mechanical injuries during harvest or handling and wound healing by exposing carrot roots to prestorage high temperature treatments can decrease predisposition of carrots to subsequent infections in storage. Treatment of carrots for 6 $\mathrm{h}$ at $25^{\circ} \mathrm{C}$ or 7 days at 15 or $25^{\circ} \mathrm{C}$ and $98 \%$ $\mathrm{RH}$ effectively reduced subsequent infection by $S$. sclerotiorum, but an inverse effect resulted when inoculum was present during the treatments (45). Periods of high temperature that provided effective wound healing on carrots in these experiments increased the level of infections by $S$. sclerotiorum, suggesting that this method may not be effective for suppressing SRC in storage. Prestorage exposure of carrot roots to $3 \mathrm{~s}$ of steam at $90^{\circ} \mathrm{C}$ suppressed disease caused by $S$. sclerotiorum, Alternaria alternata (Fr.:Fr.) Keissler, and Alternaria radicina Meier, Drechs., \& E.D. Eddy by up to $92 \%$ during 60 days in cold storage (4). The effect of steam treatments was attributed to the killing of pathogens on the carrot surface, removal of spores and debris, and stimulation of antifungal compounds in carrot roots (4).

Washing carrots before storage has had inconsistent effects on the suppression of various postharvest fungal diseases, including SRC. For instance, removal of soil by washing and culling unmarketable carrots prior to storage reduced disease by 71 to $82 \%$ and allowed for more efficient use of cold storage facilities (86). Conversely, in a similar study, prestorage washing of carrots had no consistent effect on infection by $S$. sclerotiorum (46).

Although $S$. sclerotiorum is capable of growing and causing disease at temperatures as low as $0^{\circ} \mathrm{C}$, its activity is substantially reduced below $6^{\circ} \mathrm{C}$ (41). Both $S$. sclerotiorum and $B$. cinerea produced higher levels of extracellular pectolytic enzymes and decay on the surface of carrots incubated at 20 or $1{ }^{\circ} \mathrm{C}$, when exposed to 94 to $96 \% \mathrm{RH}$, than to 98 to $100 \% \mathrm{RH}$ (146). Moreover, SRC was reduced by up to $36 \%$ when carrots were stored in icebank cooled storage at 0.5 to $1{ }^{\circ} \mathrm{C}$ and 97 to $98 \% \mathrm{RH}$, compared with conventional storage at 2 to $2.5^{\circ} \mathrm{C}$ and 85 to $95 \% \mathrm{RH}$ (46). Therefore, maintaining adequate temperature and $\mathrm{RH}$ conditions is important for reducing losses caused by SCR and sustaining long-term quality of carrots in storage.

Rapid cooling of harvested carrots is as important in disease suppression as the maintenance of optimum temperatures during storage. In commercial storage using a refrigeration coil or a Filacell cooling system, or a combination of both, cooling of bulk carrots from 6 to $1^{\circ} \mathrm{C}$ can take up to 75 days (113), whereas ice-bank cooling systems require less than $6 \mathrm{~h}$ (46). An increase of cooling time from 6 to $72 \mathrm{~h}$ increased SRC level by $300 \%$ after 15 weeks in storage at $6^{\circ} \mathrm{C}$ (113). An increase of storage temperature from 2 to $20^{\circ} \mathrm{C}$ also led to progressive increases in electrolyte leakage from carrot roots as a result of the rapid disruption and increase in permeability of cell membranes induced by $S$. sclerotiorum (41).

Chemical control. Preharvest and prestorage fungicide applications can effectively decrease the viability of sclerotia in soil or reduce levels of SRC in the field and storage, respectively. A significant decrease in carpogenic germination of sclerotia was obtained by preplant soil application of methyl bromide, formaldehyde, pentachloronitrobenzene (128), or metham-sodium (15). Several herbicides, including chlorsulfuron, cyanazine, metribuzin, triallate, and trifluralin, have also 
been shown to inhibit carpogenic germination in controlled environment studies (136). Foliar sprays with $0.3 \%$ Compass (167 g each of iprodione and thiophanatemethyl per liter; Rhône-Poulenc Agriculture) 13 and 17 weeks after seeding were effective in decreasing the level of SRC in the field and increasing marketable yield of carrots in Scotland (30). Reduction of disease development on stored carrots has been obtained by either two foliar applications of vinclozolin (Ronilan FL, $500 \mathrm{~g}$ liter $^{-1}$; BASF) at 0.42 liter a.i. ha ${ }^{-1}$, one before canopy enclosure and another in midseason, or by a single foliar application of vinclozolin at 0.84 liter a.i. ha ${ }^{-1}$ or benomyl (Benlate 50\% WP; DuPont) at $1.0 \mathrm{~kg}$ $\mathrm{ha}^{-1}, 10$ days prior to harvest (113). Disease suppression in these studies was improved when field applications of fungicides were combined with rapid cooling of harvested carrots. Similarly, one foliar application of thiophanate-methyl (Topsin M 70 WP) the day before harvest completely controlled infection by SRC in storage (132). However, proper timing of fungicidal sprays and adequate coverage of susceptible tissues of the host are crucial for obtaining effective control of Sclerotinia diseases with foliar applications $(67,128)$. In general, adequate chemical coverage of susceptible tissue is achieved in lower canopy densities and hosts with open growth habits; however, these characters are seldom compatible with high-yield requirements in commercial crops. The proper management of other foliar diseases of carrots is also important for minimizing the accumulation of additional senescent and damaged foliage that may be a suitable substrate for infection by $S$. sclerotiorum.

Effective control of SRC and subsequent reduction in crop losses during long-term storage also have been achieved by prestorage dip treatments of carrots in $0.1 \%$ aqueous solution of sodium orthophenylphenate (57), 0.05 or $0.025 \%$ a.i. suspension of benomyl, or $0.05 \%$ a.i. suspension of iprodione (Rovral 50\% WP; May \& Baker Ltd.) (26,46). Optimum storage conditions (46) and proper washing and grading of harvested carrots (86) can substantially enhance the efficacy of prestorage fungicide-dip treatments. However, although selected fungicide dips can provide additional protection and adequately suppress disease development in storage, current approved registration for postharvest fungicides is limited.

Development of fungicide resistance among pathogen populations attributed to widespread and repetitive use of fungicides is an important factor that limits the success of chemical control of most diseases. Systemic fungicides in particular, such as benomyl and other members of the benzimidazole group, are generally at high risk for development of resistance. Strains of $S$. sclerotiorum resistant to carbendazim and benomyl have been reported in rapeseed crops in France (110) and the Canadian prairies (50), respectively. Another constraint associated with chemical control is the availability of registered fungicides in different countries. In Canada for instance, the only fungicide currently registered for the control of SRC in the field is Benlate, which was recently removed from the market by the manufacturer.

Host resistance. There are no reports of carrot genotypes that possess qualitative germ plasm resistance to $S$. sclerotiorum; however, differences in the level of disease among field-grown carrot cultivars during long-term storage have been observed (41). A conductivity assay measuring electrolyte

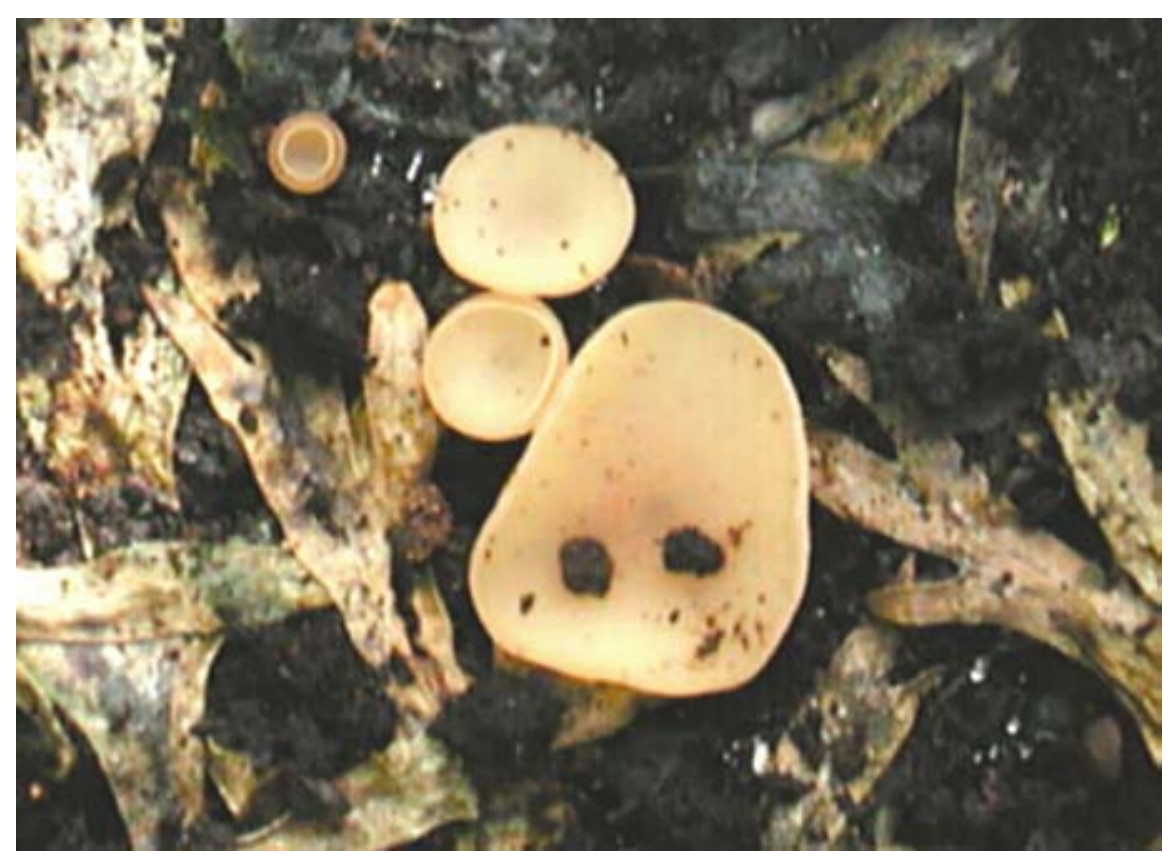

Fig. 10. Apothecia of Sclerotinia sclerotiorum in a carrot crop. leakage of carrot roots in response to infection by $S$. sclerotiorum indicated the presence of a differential susceptibility among several carrot cultivars. Variations in the integrity and permeability of root cell membranes induced by $S$. sclerotiorum in vitro were consistent with the response of the carrot cultivars to field infection and storage decay (41). These results suggested the presence of potential quantitative resistance of root tissues to cellular disruption by $S$. sclerotiorum as responsible for varying degrees of susceptibility of carrot cultivars to SRC.

Studies were conducted on several commercial carrot cultivars to evaluate the effect of differential accumulations of preformed polyacetylenes falcarindiol and falcarinol in roots on resistance to SRC (105). These polyacetylenic compounds possess strong antifungal properties and are associated with physiological resistance of carrots to other pathogens during early storage phases (44). The concentration of falcarindiol in the root periderm was negatively correlated with the susceptibility of cultivars to $S$. sclerotiorum, suggesting that falcarindiol may contribute to the resistance of carrots to SRC in storage (105). Production of falcarindiol is concentrated in root periderm and pericyclic parenchyma; it is intensively accumulated in young active roots and declines with age (84).

Qualitative resistance to $S$. sclerotiorum is absent in most cultivated host crops. However, direct associations between cultivars with an open canopy architecture and lower apothecial production, lower incidence of white mold in bean $(121,122)$ or Sclerotinia stem rot in soybean (17) crops, have been observed. Hence, management of white mold of beans has been improved by breeding for disease avoidance mechanisms such as an upright growth habit, lodging resistance, and partial physiological resistance $(43,108,119)$. Recently, several quantitative genetic traits were identified in association with resistance to $S$. sclerotiorum in various crops, including partial physiological resistance and architectural avoidance features such as canopy porosity, plant height, and lodging in beans (99) and soybeans (70). Related genetic information for interactions between carrot and $S$. sclerotiorum are not yet available.

In general, ontogenic (age-related) resistance to $S$. sclerotiorum appears to play an important role in the pattern of differential susceptibility of leaves and roots of carrot in relation to their developmental stage. In growing plants, ontogenic resistance is expressed in young and active leaves that are shown to react hypersensitively to the penetration of S. sclerotiorum (45). This reaction was attributed to the rapid response of the young leaf to infection by the induction of antifungal compounds. Ontogenic resistance decreases with leaf age, with older leaves becoming more suscepti- 
ble to infection. Variable proportions of resistant and susceptible tissues are continuously present within the carrot canopy from the onset of the first senescing leaf to harvest. However, the amount of senescent tissue usually increases progressively with the aging carrot. Similarly, the decreased resistance to pathogens observed in aging roots in storage is largely attributable to their reduced ability to accumulate antifungal compounds and the decline of their potential of wound healing (84). These resistance mechanisms need further attention since they may be important tools for improving management strategies of SRC.

Biological management. A wide range of microorganisms with antagonistic or mycoparasitic properties has been evaluated for potential to suppress diseases caused by $S$. sclerotiorum. However, attempts to investigate biological control of SRC in the field or in storage are limited to the study of various formulations of the hyperparasites $C$. minitans and Trichoderma spp.

The coelomycete $C$. minitans is hyperparasitic on a number of sclerotium-forming fungi, including S. sclerotiorum (143). $C$. minitans can penetrate, parasitize, and completely destroy sclerotia and mycelia of S. sclerotiorum by means of physical pressure and enzymatic lysis $(112,138,139)$. Soil application of solid-substrate preparations of $C$. minitans at seeding completely reduced apothecial production under canopies of artificially inoculated host and nonhost crops (94). Foliar applications of spore suspensions of $C$. minitans on Sclerotinia-infected crops reduced apothecial production by up to $90 \%$ during a 4-year rotation of crops susceptible to $S$. sclerotiorum, including carrots (47).

Foliar applications of carrot crops with the commercial bio-fungicide Contans $(C$. minitans; Prophyta Biologischer Pflanzenschutz $\mathrm{GmBH}) 6$ and 12 weeks after seeding in the field also reduced apothecial production within the crop by 35 to $100 \%$ (30). Similar treatment resulted in 18 to $35 \%$ reduction in the number of disease foci caused by $S$. sclerotiorum on carrot foliage and a $36 \%$ reduction in the proportion of infected carrot roots after 11 months in the field including in situ overwintering (30). However, better results in reducing the survival of sclerotia in rapeseed crops were obtained when $C$. minitans was applied as a soil-incorporated solidsubstrate inoculum at seeding in autumn (96). A postharvest spore suspension spray on crop residues, in addition to the preplant application of solid-substrate inoculum of $C$. minitans, further enhanced the efficacy of the hyperparasite in reducing the viability of sclerotia and infection by $S$. sclerotiorum in sequential lettuce crops (21). Additional properties that characterize $C$. minitans as a promising biological control agent for SRC include its ability to effec- tively colonize senescent tissues $(59,138)$, to persist and spread in soil (96), and to colonize (94) and reduce the viability (60) of new sclerotia produced on diseased plants. Contans is registered for commercial use in several European countries, Australia, and the United States as Intercept, and it is likely to become the product of choice for many conventional and organic growers.

Several Trichoderma spp. have demonstrated potent biocontrol activity on numerous soilborne plant-pathogenic fungi, including S. sclerotiorum. Hyphal and sclerotial parasitism by means of coiling, penetration, and lytic degradation is probably the dominant mechanism by which $T$. harzianum controls $S$. sclerotiorum $(69,126)$. It has been suggested that $T$. harzianum may also induce local and systemic resistance in the host plant (38). In soil infested with one isolate of $T$. koningii, the number of viable sclerotia was reduced by $100 \%$ within 60 days (36). Addition to soil of alginate pellets containing mycelial fragments of $T$. harzianum strain ThzID1 increased the proportion of sclerotia colonized in field plots (71).

Prestorage dip treatment for $5 \mathrm{~min}$ in a conidial suspension $\left(1 \times 10^{7}\right.$ conidia per ml) of a cold-tolerant mutant of $T$. harzianum (P1) reduced SRC severity during long-term storage at $0^{\circ} \mathrm{C}(137)$. This treatment increased the overall carrot marketable yield by $75 \%$ after 8.5 months in storage due to effective suppression of a range of storage pathogens. Since Trichoderma spp. and $C$. minitans appear to suppress SRC through different mechanisms, a combination of both may enhance the efficacy of these hyperparasites. However, future research is needed to explore this possibility with particular emphasis on the degree of compatibility between these hyperparasites.

Mycorrhizal (Glomus intraradices and Glomus etunicatum) inoculations of carrots at seeding can also provide some protection against subsequent infections by $S$. sclerotiorum in storage (51). In mycorrhizal-colonized carrots inoculated with $S$. sclerotiorum 3 months after harvest, lesions were reduced by $8 \%$ with $G$. intraradices and by $20 \%$ with $G$. etunicatum during 3 weeks in cold storage. Disease suppression by these mycorrhizal inoculants was attributed to the ability of mycorrhiza to induce defense mechanisms against $S$. sclerotiorum in carrot roots.

Soil amendments. The suppressive effect of several soil amendments on sclerotia populations has been evaluated. Amendment of field soil with an organic formulation of fermented agricultural wastes (CF-5) or allyl alcohol suppressed carpogenic germination of sclerotia and enhanced their colonization by Trichoderma spp. (63). Complete control of sclerotia 3 weeks after burial was also obtained in soil amended with an inorganic formula- tion of calcium cyanamide (Perlka; SKW Trostberg Aktiengesellschaft, Germany) in controlled environment (65).

Alternative methods. Chitosan, a naturally derived polysaccharide, has antifungal properties to $S$. sclerotiorum and has been suggested as a postharvest treatment for the control of SRC in storage (26). Coating carrot roots with solutions of chitosan reduced the size of the lesions caused by subsequent $S$. sclerotiorum infections by up to $53 \%$ and decreased incidence of SRC by up to $68 \%$. Exposure of S. sclerotiorum to chitosan induced hyphal deformation and death, explaining some aspects of the inhibitory mechanisms of this compound (26). Chitosan is believed to possess a dual mechanism of action that interferes with fungal growth and acts as an elicitor by activating defense mechanisms in plant tissues (37). The use of chitosan as a prestorage treatment for disease control appears promising, but the effect of this treatment on storage duration and quality of stored carrots needs further research.

Nonionizing ultraviolet (UV-C) radiation can effectively elicit the accumulation of the antifungal phytoalexin 6-methoxymellein (6-MM) in carrot roots and, hence, induce systemic resistance to subsequent infections by S. sclerotiorum (97). Treatment with UV-C radiation at a dose of $2.20 \times 10^{5} \mathrm{erg} \mathrm{cm}^{-2}$ induced accumulation of 6-MM to maximal inhibitory levels (e.g., $60 \mu \mathrm{g} \mathrm{g}^{-1}$ ) and reduced the growth of S. sclerotiorum on carrot slices incubated at 1 or $4^{\circ} \mathrm{C}$. However, integration of UV treatments with other control strategies is recommended for a prolonged protective effect (37).

Ozone has demonstrated fungistatic effects on S. sclerotiorum and was proposed as an alternative disinfectant for stored carrots (85). Treatments with gaseous flow of ozone reduced the daily growth rate of $S$. sclerotiorum on inoculated carrots by ca. $50 \%$. However, concentrations of $60 \mu \mathrm{l}$ of ozone per liter in air caused significant physiological disruptions, including increased respiration rate, electrolyte leakage, and discoloration of carrots. Therefore, an ozone supply of $15 \mu$ liter $^{-1}$ for $8 \mathrm{~h}$ daily at $2^{\circ} \mathrm{C}$ was suggested for providing adequate disease control while preserving carrot quality.

Disease modeling and forecasting. Modeling or forecasting of epidemics of SRC in the field has not been reported. However, several forecasting systems have been proposed for predicting diseases caused by $S$. sclerotiorum in other crops $(20,68,142,144)$. The occurrence of ascospores and incidence of white mold in snap bean crops were best predicted using soil matric potential thresholds (68). Models that best predicted the risk of stem rot of rapeseed and the need for fungicide application included combinations of selected environmental and crop variables such as rainfall, soil moisture, canopy density, 
petal infestation by S. sclerotiorum, blooming patterns, and cropping history $(20,141,144)$. These models may offer a promising avenue to pursue for the management of SRC.

In storage, monitoring headspace volatile metabolites may be a useful method for early detection and quantification of SRC. Comparative analyses of volatile profiles of infected and healthy roots identified at least one compound, dichlorobenzene, that was specific to carrots infected by $S$. sclerotiorum and may qualify as a disease indicator (106). Incorporating the monitoring of volatiles as an integral component of an automated logging system of storage environment may contribute to rapid intervention and prevention of SRC outbreaks.

In summary, only a few of the methods and products tested for the management of SRC have obtained large-scale application in commercial carrot crops. Moreover, several of the tested products may not be commercially available in all countries. Therefore, the control practices currently applied by growers in different countries to manage SRC in the field and storage depend on the availability of products and technology. In Israel, for instance, foliar spray applications of winter carrot crops with benomyl, carbendazim, or iprodione at 14-day intervals starting immediately after canopy enclosure, and prestorage hydrocooling, are widespread practices (E. Shlevin, Kibbutz Saad, Plant Protection R\&D Group, Israel, personal communication). In the UK, Compass (Aventis
CropScience UK Ltd.) has been granted off-label approval for use to control SRC in commercial carrots because of good results obtained in other crops (30). In the western United States, satisfactory control of SRC is achieved by multiple lateral trimmings of the carrot canopy (T. Crosby, Mercer Ranch, WA, personal communication). Prevailing dry winds and low humidity in this farming area are particularly beneficial to the effect of trimming; however, this technique also may be suitable in areas with different weather patterns. Lateral trimming is a cultural method that removes portions of the carrot canopy to improve ventilation and reduce free moisture within the crop, to reduce senescent foliage, and to avoid plant-tosoil contact (131). In Canada, the absence of available preharvest and postharvest fungicides and extended periods of storage have encouraged growers to focus on methods that suppress disease development in storage such as proper grading, rapid cooling of harvested crop using hydro- or forced cold air-cooling systems, and maintenance of optimum storage conditions.

The primary approach to managing SRC is perhaps the integration of methods that disrupt various stages of the life cycle of $S$. sclerotiorum and manipulation of the attributes of carrot crops that contribute to disease development, i.e., canopy enclosure, foliar senescence, and lodging. A diagram summarizing an emerging integrated disease management model for SRC that accounts for the decreasing availability

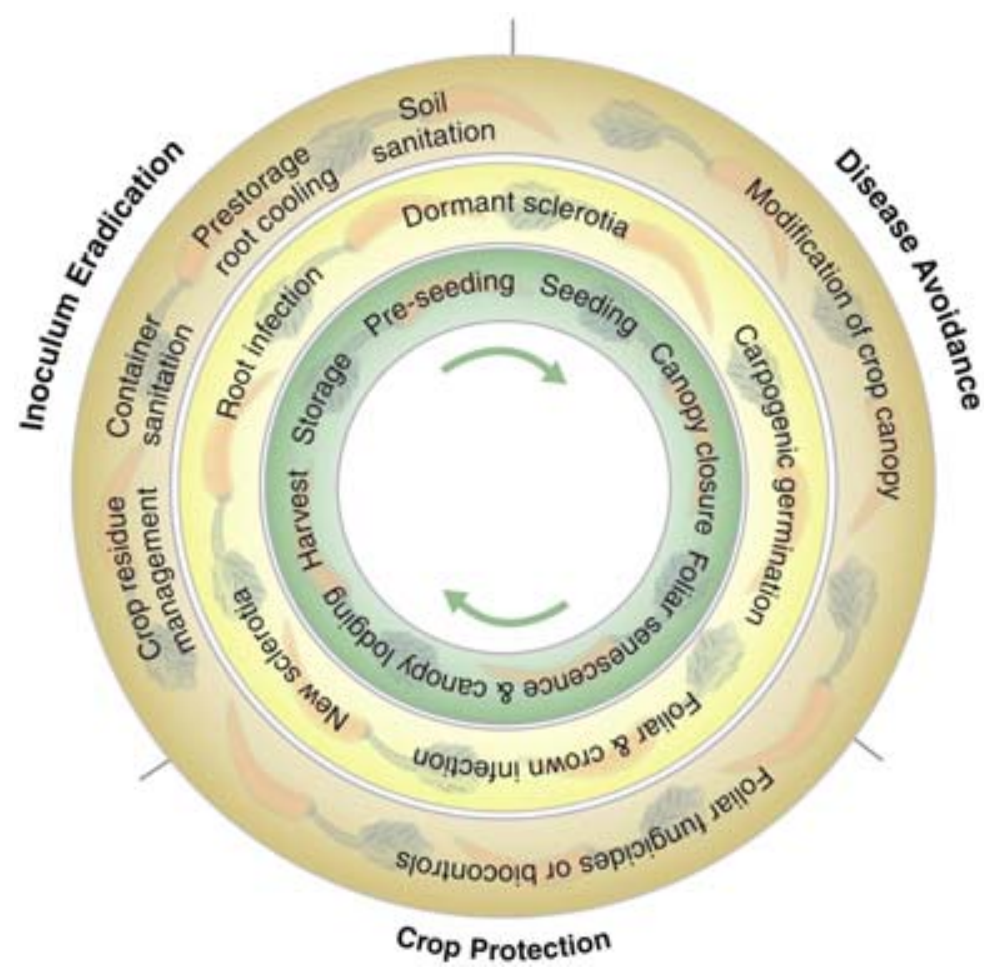

Fig. 11. An integrated model for managing Sclerotinia rot of carrot that incorporates three disease management principles and selected disease control strategies (outer circle) that target particular stages in the life cycle of Sclerotinia sclerotiorum (middle circle) or development of the carrot crop (inner circle). Control strategies corresponding to respective stages are indicated by positional overlap.

of some disease management products, such as fumigants and prestorage fungicides, and the increasing availability of new products, such as biological controls, is presented in Figure 11. Sanitation of soil prior to seeding (e.g., steam sterilization) and treatment of crop residues remained in the field after harvest (e.g., Contans, deep plowing) aim at reducing the reservoir of viable sclerotia in soil. Modification of crop canopy (e.g., wide row spacing, balanced nitrogen inputs, or lateral trimming) aim at rendering the microclimate and the crop less conducive for the development of S. sclerotiorum and avoidance of SRC. Further, timed and need-based applications of fungicides or biological controls aim at protecting the crop from infection. An open canopy achieved by modification would be beneficial in improving the accessibility of materials to reach potential infection sites at the plant base. Sanitation of containers, storage facilities, and handling equipment (e.g., using disinfectants), rapid cooling of the roots, along with maintenance of optimum storage conditions aim at reducing the inoculum and suppressing the development of SRC in storage. The proper coordination of these methods is likely to provide economically acceptable results for the management of SRC in commercial production systems.

\section{Summary and Future Research}

The epidemiology of SRC is distinct from several other Sclerotinia diseases because it is characterized by two interconnected epidemics involving preharvest foliar infection in the field and postharvest root infection in storage. The sporadic nature of SRC, the asymptomatic characteristic of diseased roots at harvest, and the lack of correlation between infection levels in both epidemics have restricted current attempts to establish disease thresholds and prediction of yield loss in storage. Investigation of etiological aspects of disease progress from leaves to the root and the influence of preharvest environmental and physiological factors on postharvest development of disease would contribute toward a better understanding of qualitative and quantitative attributes of SRC epidemics.

Several architectural and phenological attributes of carrot crops appear to be significant for the epidemiology of SRC. The development of the canopy may affect the production of inoculum within the crop, and older senescing leaves in the lower canopy provide a continuum of substrate favorable for infection by $S$. sclerotiorum. Therefore, knowledge of relationships between the growth stages of $S$. sclerotiorum and carrot phenology is essential in integrating management tactics that target the most vulnerable stages of the pathogen and the crop attributes that contribute to disease development in the field. Development of carrot growth models that incorporate canopy closure, foliar senes- 
cence, and canopy lodging would be a useful tool for the prediction of SRC epidemics and improved management of this disease.

The main limiting factors for the management of SRC are related to the attributes of S. sclerotiorum such as the longterm persistence of sclerotia in soil, the wide host range and ubiquitous distribution, the ability to produce infective propagules in synchrony with the susceptible stage of the host, and the ability to infect in temperatures as low as 0 to $1^{\circ} \mathrm{C}$. Current intensive carrot cultivation practices characterized by large cropping areas, high plant densities, high inputs, short-term rotations, and the use of high-yielding carrot cultivars with extensive canopy growth can be particularly conducive to the development of S. sclerotiorum and SRC epidemics. Moreover, optimal combinations of weather conditions favorable for the development of $S$. sclerotiorum and carrot can incite widespread epidemics.

Most research on the resistance of carrots to SRC has been related to partial and physiological resistance of roots during storage. Experience with other crops indicates that it may be promising to investigate potential disease avoidance mechanisms such as open and upright plant architecture as a source for selecting new carrot cultivars. Perhaps further research needs to focus on breeding carrot cultivars selected for a combination of compact, lodging-resistant canopy growth traits and the ability to accumulate effective levels of antifungal compounds in roots for improved resistance to infection by $S$. sclerotiorum in storage.

\section{Acknowledgments}

We greatly acknowledge the financial support provided by the Natural Sciences and Engineering Research Council of Canada (NSERC) and Ontario Ministry of Agriculture and Food (OMAF). We also wish to thank Douglas C. Schaefer and Michael J. Castledine for their assistance with the graphical presentation of the disease cycle and the disease management diagram, respectively, as well as all our colleagues who contributed to this paper through personal communication and discussion.

\section{Literature Cited}

1. Abawi, G. S., and Grogan, R. G. 1975. Source of primary inoculum and effects of temperature and moisture on infection of beans by Whetzelinia sclerotiorum. Phytopathology 65:300-309.

2. Abawi, G. S., and Grogan, R. G. 1979. Epidemiology of diseases caused by Sclerotinia species. Phytopathology 69:899-904.

3. Adams, P. B., and Ayres, W. A. 1979. Ecology of Sclerotinia species. Phytopathology 69:896-899.

4. Afek, U., Orenstein, J., and Nuriel, E. 1999. Steam treatment to prevent carrot decay during storage. Crop Prot. 18:639-642.

5. American Phytopathological Society Committee on Standardization of Common Names for Plant Diseases. 1994. Carrots. In: Common Names for Plant Diseases. Online, updated publication 05/25/2000. APS, St. Paul, MN.
6. Anonymous. 1931. Carrot. Can. Plant Dis. Surv.: 37.

7. Anonymous. 1934. Carrot. Can. Plant Dis. Surv.: 37.

8. Anonymous. 1961. Diseases of carrots and parsnips. Tasman. J. Agric. 32:63-67.

9. Anonymous. 1970. Carrot. Can. Plant Dis. Surv. 50:20

10. Anonymous. 2001. 2000 FAO Production Yearbook, Vol. 54. FAO, Rome, Italy.

11. Anas, O., and Reeleder, R. D. 1987. Recovery of fungi and arthropods from sclerotia of Sclerotinia sclerotiorum in Quebec muck soils. Phytopathology 77:327-331.

12. Arsvoll, K. 1971. Important storage diseases of carrots in Norway. Acta Hortic. 20:125129.

13. Bedlan, G. 1984. Wichtige krankheiten der Karotten. Der Pflanzenarzt 37:140-142.

14. Ben-Yephet, Y., and Bitton, S. 1985. Use of selective medium to study the dispersal of ascospores of S. sclerotiorum. Phytoparasitica 13:33-40.

15. Ben-Yephet, Y., Bitton, S., and Greenberger, A. 1986. Control of lettuce drop disease, caused by Sclerotinia sclerotiorum, with metham-sodium soil treatment and foliar application of benomyl. Plant Pathol. 35:146151.

16. Boland, G. J., and Hall, R. 1987. Epidemiology of white mold of white bean in Ontario. Can. J. Plant Pathol. 9:218-224.

17. Boland, G. J., and Hall, R. 1987. Evaluating soybean cultivars for resistance to Sclerotinia sclerotiorum under field conditions. Plant Dis. 71:934-936.

18. Boland, G. J., and Hall, R. 1988. Epidemiology of Sclerotinia stem rot of soybean in Ontario. Phytopathology 78:1241-1245.

19. Boland, G. J., and Hall, R. 1994. Index of plant hosts of Sclerotinia sclerotiorum. Can. J. Plant Pathol. 16:93-108.

20. Bom, M., and Boland, G. J. 2000. Evaluation of disease forecasting variables for sclerotinia stem rot (Sclerotinia sclerotiorum) of canola. Can. J. Plant Sci. 80:889-898.

21. Budge, S. P., McQuilken, M. P., Fenlon, J. S., and Whipps, J. M. 1995. Use of Coniothyrium minitans and Gliocladium virens for biological control of Sclerotinia sclerotiorum in glasshouse lettuce. Biol. Control 5:513-522.

22. Caesar, A. J., and Pearson, R. C. 1983. Environmental factors affecting survival of ascospores of Sclerotinia sclerotiorum. Phytopathology 73:1024-1030.

23. Carpenter, M. A., Frampton, C., and Stewart, A. 1999. Genetic variation in New Zealand populations of the plant pathogen Sclerotinia sclerotiorum. N.Z. J. Crop Hortic. Sci. 27:13-21.

24. Cartia, G., Cipriano, T., and Quartarone, G. 1987. Impiego della "solarizzazione" del suolo e di fumiganti nei confronti di parasiti ipogei della carota in Sicilia. Inf. Fitopatol. 37:43-46.

25. Cessna, S. G., Sears, V. E., Dickman, M. B., and Low, P. S. 2000. Oxalic acid, a pathogenicity factor for Sclerotinia sclerotiorum, suppresses the oxidative burst of the host plant. Plant Cell 12:2119-2200.

26. Cheah, L. H., Page, B. B. C., and Shepherd, R. 1997. Chitosan coating for inhibition of sclerotinia rot of carrot. N.Z. J. Crop Hortic. Sci. 25:89-92

27. Cline, M. N., and Jacobsen, B. J. 1983. Methods of evaluating soybean cultivars for resistance to Sclerotinia sclerotiorum. Plant Dis. 67:784-786.

28. Coley-Smith, J. R., and Cooke, R. C. 1971. Survival and germination of fungal sclerotia. Annu. Rev. Phytopathol. 9:65-92.

29. Cook, G. E., Steadman, J. R., and Boosalis,
M. G. 1975. Survival of Whetzelinia sclerotiorum and initial infection of dry edible beans in western Nebraska. Phytopathology 65:250-255.

30. Couper, G. 2001. The biology, epidemiology and control of Sclerotinia sclerotiorum on carrots in North East Scotland. Ph.D. thesis. University of Aberdeen, Aberdeen, Scotland, UK.

31. Cubeta, M. A., Cody, B. R., Hudyncia, J., and Shew, H. D. 1998. Ecology and population biology of Sclerotinia sclerotiorum on cabbage in eastern North Carolina. Pages 3233 in: Proc. Int. Sclerotinia Workshop10th. B. D. Nelson and T. J. Gulya, eds. BSPP and ISPP, Fargo, ND.

32. Cubeta, M. A., Cody, B. R., Kohli, Y., and Kohn, L. M. 1997. Clonality in Sclerotinia sclerotiorum on infected cabbage in eastern North Carolina. Phytopathology 87:10001004.

33. de Jong, C. B. 1990. Sclerotinia sclerotiorum as the causal agent of storage decay in winter carrots, chicory and celery. Gewasbescherming 21:59-64.

34. Dillard, H. R., and Hunter, J. E. 1986. Association of common ragweed with Sclerotinia rot of cabbage in New York state. Plant Dis. 70:26-28.

35. Djacenko, V. S. 1971. Some biological peculiarities and storage methods of carrots. Acta Hortic. 20:80-91.

36. Dos Santos, A. F., and Dhingra, O. D. 1982. Pathogenicity of Trichoderma spp. on the sclerotia of Sclerotinia sclerotiorum. Can. J. Bot. 60:472-475.

37. El Ghaouth, A. 1994. Manipulation of defense systems with elicitors to control postharvest diseases. Pages 153-167 in: Biological Control of Postharvest Diseases - Theory and Practice. C. L. Wilson and M. E. Wisniewski, eds. CRC Press, Boca Raton, FL.

38. Elad, Y. 2000. Biological control of foliar pathogens by means of Trichoderma harzianum and potential modes of action. Crop Prot. 19:709-714.

39. El-Tobshy, Z. M., and Zayed, M. A. 1979. Post-harvest Sclerotinia soft rot of squash and carrot. Agric. Res. Rev. (Cairo) 57:4756.

40. Ferraz, L. C. L., Café Filho, A. C., Nasser, L. C. B., and Azevedo, J. 1999. Effects of soil moisture, organic matter and grass mulching on the carpogenic germination of sclerotia and infection of bean by Sclerotinia sclerotiorum. Plant Pathol. 48:77-82.

41. Finlayson, J. E., Pritchard, M. K., and Rimmer, S. R. 1989. Electrolyte leakage and storage decay of five carrot cultivars in response to infection by Sclerotinia sclerotiorum. Can. J. Plant Pathol. 11:313316

42. Finlayson, J. E., Rimmer, S. R., and Pritchard, M. K. 1989. Infection of carrots by Sclerotinia sclerotiorum. Can. J. Plant Pathol. 11:242-246.

43. Fuller, P. A., Steadman, J. R., and Coyne, D P. 1984. Enhancement of white mold avoidance in dry beans by canopy elevation. HortScience 19:78-79.

44. Garrod, B., and Lewis, B. G. 1982. The effect of falcarindiol on hyphal growth of Mycocentrospora acerina. Trans. Br. Mycol. Soc. 75:166-169.

45. Geary, J. R. 1978. Host-parasite interactions between the cultivated carrot (Daucus carota L.) and Sclerotinia sclerotiorum (Lib.) de Bary. Ph.D. thesis. University of East Anglia, East Anglia, UK.

46. Geeson, J. D., Browne, K. M., and Everson, H. P. 1988. Storage diseases of carrots in East Anglia 1978-82, and the effects of some 
pre- and post-harvest factors. Ann. Appl. Biol. 112:503-514.

47. Gerlagh, M., Goossen-van de Geijn, H. M., Fokkema, N. J., and Vereijken, P. F. G. 1999. Long-term biosanitation by application of Coniothyrium minitans on Sclerotinia sclerotiorum-infected crops. Phytopathology 89:141-147.

48. Ginns, J. H. 1986. Compendium of Plant Diseases and Decay Fungi in Canada 1960-
1980. Research Branch, Agriculture Canada, Ottawa, Ontario.

49. Godoy, G., Steadman, J. R., Dickman, M. B., and Dam, R. 1990. Use of mutants to demonstrate the role of oxalic acid in pathogenicity of Sclerotinia sclerotiorum on Phaseolus vulgaris. Physiol. Mol. Plant Pathol. 37:179-191.

50. Gossen, B. D., and Rimmer, S. R. 2001. First report of resistance to benomyl fungicide in
Sclerotinia sclerotiorum. Plant Dis. 85:1206.

51. Gotoéchan, H. M. 1999. Effets de deux inoculants endomycorhiziens commerciaux sur le rendement et la qualité de la carotte (Daucus carota $\mathrm{L}$.) en champ et sur le dévéloppement de deux maladies en entrepôt. M.Sc. thesis. Laval University, Quebec, Canada.

52. Gracia-Garza, J. A., Bailey, B. A., Paulitz, T. C., Lumsden, R. D., Reeleder, R. D., and Roberts, D. P. 1997. Effect of sclerotial dam-

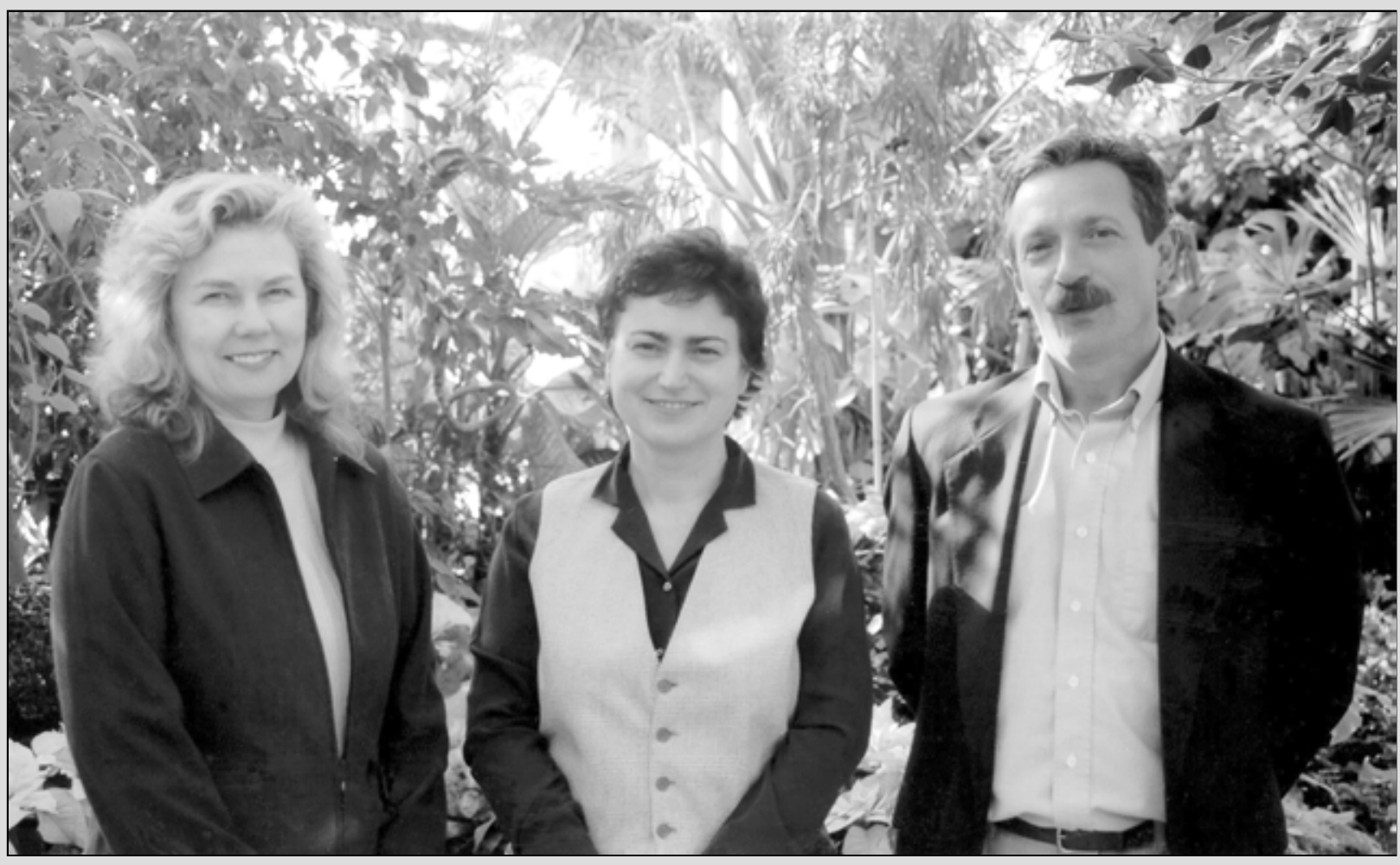

Mary Ruth McDonald

Cezarina Kora

Greg J. Boland

Ms. Kora is currently completing her Ph.D. in the Department of Environmental Biology, University of Guelph. She received her B.Sc. in Agronomy from the Agricultural University of Tirana, Albania, in 1983. From 1985 to 1991 she worked as a plant pathologist for the Agricultural State Farm in Durres, Albania, specializing in greenhouse tomato diseases. During 1992 to 1995, she was jointly employed by United Nations Food and Agriculture Organization (FAO) and the Ministry of Agriculture and Food of Albania to coordinate a cooperation project focused on strengthening agricultural policies and resource management practices in Albania. Cezarina enrolled in a Ph.D. program in 1998 and was awarded a Natural Sciences and Engineering Research Council of Canada (NSERC) Scholarship from 2000 to 2002. Her research is focused on the study of the etiology, epidemiology, and management of Sclerotinia rot of carrot in organic soils. Cezarina's research interests include the use of disease forecasting systems as decision support tools for the integrated management of diseases and the development of alternative methods of disease control.

Dr. McDonald is an assistant professor in the Department of Plant Agriculture at the University of Guelph in Guelph, Ontario, Canada. She received her B.Sc. degree, with a major in plant protection, from the University of Guelph and her M.Sc. and Ph.D. degrees in plant pathology, also from the University of Guelph. She started her career as an extension potato pathologist for the Prince Edward Island Department of Agriculture, and later worked as a pest management specialist on muck vegetables for the Ontario Ministry of Agriculture and Food. In 1989 she accepted the position of Chief Scientist of the Muck Crops Research Station, again with Ontario Ministry of Agriculture and Food, and in 1997 she joined the University of Guelph. Her research program focuses on the forecasting and management of diseases of carrots, onions, and other vegetable crops and the development of integrated crop management systems for these vegetables. Mary Ruth is co-chair of the International Allium White Rot Working Group.

Dr. Boland is a professor of plant pathology in the Department of Environmental Biology, University of Guelph. He received his B.Sc. and M.Sc. degrees in mycology from Acadia University, Nova Scotia, Canada, and his Ph.D. in plant pathology from the University of Guelph. He joined the faculty at the University of Guelph in 1984, and has had a research leave at the University of Wisconsin, Madison. in 1985, and sabbatical leaves with Agriculture and Agri-Food Canada in Vancouver and Saskatoon in 1991 and 1998, respectively. He served as a visiting lecturer in Trinidad with the International Development Research Centre (IDRC) and Inter-American Institute for Cooperation in Agriculture (IICA) in 1990 and 1991. He was awarded the Canadian Phytopathological Society's Gordon J. Green Young Scientist Medal in 1996, and served as President of the Canadian Phytopathological Society in 2001-2002. Dr. Boland is currently serving as the Immediate Past President and Website Editor of CPS. His research interests include the biology and ecology of fungal plant pathogens, with emphasis on hypovirulence, biological control, epidemiology, and disease management. 
age of Sclerotinia sclerotiorum on the mycoparasitic activity of Trichoderma harzianum. Biocontrol Sci. Technol. 7:401-413.

53. Grogan, R. G., and Abawi, G. S. 1975. Influence of water potential on growth of and survival of Whetzelinia sclerotiorum. Phytopathology 69:908-910.

54. Hancock, J. G. 1967. Hemicellulose degradation in sunflower hypocotyls infected with Sclerotinia sclerotiorum. Phytopathology 57:203-206.

55. Hansen, J. M. Tobias, D. J., Balbyshev, N. F., Stack, R. W., and Lee, C. W. 2001. Effect of preharvest benomyl spray on winter storage of carrots. (Abstr.) Phytopathology 91:S178.

56. Hartill, W. F. T. 1980. Aerobiology of Sclerotinia sclerotiorum and Botrytis cinerea spores in New Zealand tobacco crops. N.Z. J. Agric. Res. 23:259-262.

57. Hoadley, A. D. 1963. Control of carrot storage disease organisms with sodium orthophenylphenate. Plant Dis. Rep. 47:900903.

58. Holst-Jensen, A., Kohn, L. M., and Schumacher, T. 1997. Nuclear rDNA phylogeny of the Sclerotiniaceae. Mycologia 89:885-899.

59. Huang, H. C. 1977. Importance of Coniothyrium minitans in survival of sclerotia of Sclerotinia sclerotiorum in wilted sunflower. Can. J. Bot. 55:289-295.

60. Huang, H. C., Bremer, E., Hynes, R. K., and Erickson, R. S. 2000. Foliar application of fungal biocontrol agents for the control of white mold of dry bean caused by Sclerotinia sclerotiorum. Biol. Control 18:270276.

61. Huang, H. C., and Dueck, J. 1980. Wilt of sunflower from infection by mycelial-germinating sclerotia of Sclerotinia sclerotiorum. Can. J. Plant Pathol. 2:47-52.

62. Huang, H. C., and Hoes, J. A. 1980. Importance of plant spacing and sclerotial position to development of Sclerotinia wilt of sunflower. Plant Dis. 64:81-84.

63. Huang, H. C., Huang, J. W., Snaidon, G., and Erickson, R. S. 1997. Effect of allyl alcohol and fermented agricultural wastes on carpogenic germination of sclerotia of Sclerotinia sclerotiorum and colonization by Trichoderma spp. Can. J. Plant Pathol. 19:43-46.

64. Huang, H. C., and Kozub, G. C. 1991. Temperature requirements for carpogenic germination of sclerotia of Sclerotinia sclerotiorum isolates of different geographic region. Bot. Bull. Acad. Sin. 32:279-286.

65. Huang, H. C., and Sun, S. K. 1991. Effects of S-H mixture or Perlka on carpogenic germination and survival of sclerotia of Sclerotinia sclerotiorum. Soil Biol. Biochem. 23:809-813.

66. Hudyncia, J., Shew, H. D., Cody, B. R., and Cubeta, M. A. 2000. Evaluation of wounds as a factor to infection of cabbage by ascospores of S. sclerotiorum. Plant Dis. 84:316320.

67. Hunter, J. E., Abawi, G. S., and Crosier, D. C. 1978. Effects of timing, coverage, and spray oil on control of white mold of snap bean with benomyl. Plant Dis. Rep. 62:633637.

68. Hunter, J. E., Pearson, R. C., Seem, R. C., Smith, C. A., and Palumbo, D. R. 1984. Relationship between soil moisture and occurrence of Sclerotinia sclerotiorum and white mold disease on snap beans. Prot. Ecol. 7:269-280.

69. Inbar, J., Menendez, A., and Chet, I. 1996. Hyphal interaction between Trichoderma harzianum and Sclerotinia sclerotiorum and its role in biological control. Soil Biol. Biochem. 28:757-763.
70. Kim, H. S., and Diers, B. W. 2000. Inheritance of partial resistance to sclerotinia stem rot in soybean. Crop Sci. 40:55-61.

71. Knudsen, G. R., Eschen, D. J., Dandurand, L. M., and Bin, L. 1991. Potential for biocontrol of Sclerotinia sclerotiorum through colonization of sclerotia by Trichoderma harzianum. Plant Dis. 75:466-470.

72. Kohli, Y., and Kohn, L. M. 1998. Detection of random association among loci in clonal population of Sclerotinia sclerotiorum. Fungal Genet. Biol. 23:139-149.

73. Kohli, Y., Morrall, R. A. A., Anderson, J. B., and Kohn, L. M. 1992. Local and trans-canadian clonal distribution of Sclerotinia sclerotiorum on canola. Phytopathology 82:875880.

74. Kohn, L. M. 1979. A monographic revision of the genus Sclerotinia. Mycotaxon 9:365444.

75. Kohn, L. M., Carbone, I., and Anderson, J. B. 1990. Mycelial interaction in Sclerotinia sclerotiorum. Exp. Mycol. 14:255-267.

76. Kohn, L. M., Petsche, D. M., Bailey, S. R., Novak, L. A., and Anderson, J. B. 1988. Restriction fragment length polymorphisms in nuclear and mitochondrial DNA of Sclerotinia species. Phytopathology 78:10471051.

77. Kohn, L. M., Stasovski, E., Carbone, I., Royer, J., and Anderson, J. B. 1991. Mycelial incompatibility and molecular markers identify genetic variability in field populations of Sclerotinia sclerotiorum. Phytopathology 81:480-485.

78. Kucmierz, J., Bartynska, M., and Mazur, S. 1989. Studies of fungal diseases on carrot grown for seeds. Rocz. Akad. Roln. Poznan 194:171-178.

79. Kull, L. S., Pedersen, W. L., and Hartman, G. L. 2001. Mycelial compatibility grouping and aggressiveness of Sclerotinia sclerotiorum. Pages 23-24 in: Proc. Int. Sclerotinia Workshop 11th. C. Young and K. Hughes, eds. BSPP and ISPP, York, UK.

80. Lauritzen, J. I. 1932. Development of certain storage and transit diseases of carrot. J. Agric. Res. 44:861-912.

81. Le Cam, B., Rouxel, F., and Villeneuve, F. 1993. Analyse de la flore fongique de la carotte conservée au froid: prépondérance de Mycocentrospora acerina (Hartig) Deighton. Agronomie 13:125-133.

82. Le Tourneau, D. 1979. Morphology, cytology and physiology of Sclerotinia species in culture. Phytopathology 69:887-890.

83. Letham, D. B., Huett, D. O., and Trimboli, D. S. 1979. Biology and control of Sclerotinia sclerotiorum in cauliflower and tomato crops in coastal New South Wales. Plant Dis. Rep. 60:286-289.

84. Lewis, B. G., and Garrod, B. 1983. Carrots. Pages 103-124 in: Post-Harvest Pathology of Fruits and Vegetables. C. Dennis, ed. Academic Press, London.

85. Liew, C. L., and Prange, R. K. 1994. Effect of ozone and storage temperature on postharvest diseases and physiology of carrots (Daucus carota L.). J. Am. Soc. Hortic. Sci. 119:563-567.

86. Lockhart, C. L., and Delbridge, R. W. 1972. Control of storage diseases of carrots by washing, grading, and postharvest fungicide treatments. Can. Plant Dis. Surv. 52:140142.

87. Lumsden, R. D. 1969. Sclerotinia sclerotiorum infection of bean and the production of cellulase. Phytopathology 59:653-657.

88. Lumsden, R. D. 1970. Phosphatidase of Sclerotinia sclerotiorum produced in culture and in infected bean. Phytopathology 60:1106-1110

89. Lumsden, R. D. 1979. Histology and physi- ology of pathogenesis in plant diseases caused by Sclerotinia species. Phytopathology 69:890-896.

90. Luz, N. K. 1970. Fungos de plantas olericolas no Rio Grande do Sul. Pesqui. Agropecu. Bras. 5:53-59.

91. Mackevic, V. I. 1929. The carrot of Afghanistan. Bull. Appl. Bot., Genet. Plant $\mathrm{Br}$ 20:517-562

92. Marciano, P., Di Lenna, P., and Magro, P. 1983. Oxalic acid, cell-degrading enzymes and $\mathrm{pH}$ in pathogenesis and their significance in the virulence of two Sclerotinia sclerotiorum isolates on sunflower. Physiol. Plant Pathol. 22:339-345.

93. Maxwell, D. P., and Lumsden, R. D. 1970 Oxalic acid production by Sclerotinia sclerotiorum in infected bean and in culture. Phytopathology 60:1395-1398.

94. McLaren, D. L., Huang, H. C., and Rimmer, S. R. 1996. Control of apothecial production of Sclerotinia sclerotiorum by Coniothyrium minitans and Talaromyces flavus. Plant Dis. 80:1373-1378

95. McLean, D. M. 1958. Role of dead flower parts in infection of certain crucifers by Sclerotinia sclerotiorum (Lib.) de Bary. Plant Dis. Rep. 42:663-666.

96. McQuilken, M. P., Mitchel, S. J., Budge, S P., Whipps, J. M., Fenlon, J. S., and Archer, S. A. 1995. Effect of Coniothyrium minitans on sclerotial survival and apothecial production of Sclerotinia sclerotiorum in fieldgrown oilseed rape. Plant Pathol. 44:883896

97. Mercier, J., Arul, J., Ponnampalam, R., and Boulet, M. 1993. Induction of 6-Methoxymellein and resistance to storage pathogens in carrot slices by UV-C. J. Phytopathol. 137:44-54.

98. Merriman, P. R., Pywell, M., Harrison, G., and Nancarrow, J. 1979. Survival of sclerotia of Sclerotinia sclerotiorum and effects of cultivation practices on disease. Soil Biol. Biochem. 11:567-570.

99. Miklas, P. N., Johnson, W. C., Delorme, R., and Gepts, P. 2001. QTL conditioning physiological resistance and avoidance to white mold in dry bean. Crop Sci. 41:309315.

100. Moore, W. D. 1949. Flooding as a means of destroying sclerotia of Sclerotinia sclerotiorum. Phytopathology 39:920-927.

101. Morrall, R. A. A. 1977. A preliminary study of the influence of water potential on sclerotium germination in Sclerotinia sclerotiorum. Can. J. Bot. 55:8-11.

102. Morrall, R. A. A., and Dueck, J. 1982. Epidemiology of sclerotinia stem rot of rapeseed in Saskatchewan. Can. J. Plant Pathol. 4:161-168.

103. Mukula, J. 1957. On the decay of stored carrots in Finland. Acta Agric. Scand. Suppl.

104. Newton, H. K., and Sequeira, L. 1972. Ascospores as the primary infective propagule of Sclerotinia sclerotiorum in Wisconsin. Plant Dis. Rep. 56:798-802

105. Olsson, K., and Svensson, R. 1996. The influence of polyacetylenes on the susceptibility of carrots to storage diseases. J. Phytopathol. 144:441-447.

106. Ouellette, E., Raghavan, G. S. V., and Reeleder, R. D. 1990. Volatile profiles for disease detection in stored carrots. Can. Agric. Eng. 32:255-261.

107. Palti, J. 1963. Sclerotinia sclerotiorum in Israel. Phytopathol. Mediterr. 2:60-64.

108. Park, S. J. 1993. Response of bush and upright plant type selections to white mold and seed yield of common beans grown in various row widths in southern Ontario. Can. J. Plant Sci. 73:265-272. 
109. Patterson, C. L., and Grogan, R. G. 1985. Differences in epidemiology and control of lettuce drop caused by Sclerotinia minor and S. sclerotiorum. Plant Dis. 69:766-770.

110. Penaud, A., Huguet, B., Wilson, V., and Leroux, P. 2001. Benzimidazole resistance of Sclerotinia sclerotiorum in French oilseed rape crops. Pages 117-118 in: Proc. Int. Sclerotinia Workshop 11th. C. Young and K. Hughes, eds. BSPP and ISPP, York, UK.

111. Phillips, A. J. L. 1990. The effects of soil solarization on sclerotial populations of Sclerotinia sclerotiorum. Plant Pathol. 39:38-43.

112. Phillips, A. J. L., and Price, K. 1983. Structural aspects of the parasitism of sclerotia of Sclerotinia sclerotiorum (Lib.) de Bary by Coniothyrium minitans Campb. Phytopathol. Z. 107:193-203.

113. Pritchard, M. K., Boese, D. E., and Rimmer, S. R. 1992. Rapid cooling and field-applied fungicides for reducing losses in stored carrots caused by cottony soft rot. Can. J. Plant Pathol. 14:177-181.

114. Purdy, L. H. 1979. Sclerotinia sclerotiorum: History, diseases and symptomatology, host range, geographic distribution, and impact. Phytopathology 69:875-880.

115. Rader, W. E. 1952. Diseases of stored carrots in New York State. N.Y. Agric. Exp. Stn. Geneva Bull. No. 889:10-14.

116. Riou, C., Fraissinet-Tachet, L., G., F., and Fevre, M. 1992. Secretion of pectic isoenzymes by Sclerotinia sclerotiorum. FEMS Microbiol. Lett. 91:231-238.

117. Roy, A. K. 1973. Host range of Sclerotinia sclerotiorum and Sclerotium rolfsii in Jorhat, Assam. Sci. Cult. 39:319-320.

118. Rubatzky, V. E., Quiros, C. F., and Simon, P. W. 1999. Carrots and related vegetable Umbelliferae. CABI Publishing, New York.

119. Saindon, G., Huang, H. C., Kozub, G. C., Mundel, H. H., and Kemp, G. A. 1993. Incidence of white mold and yield of upright bean grown in different planting patterns. J. Phytopathol. 137:118-124.

120. Salunkhe, D. K., and Desai, B. B. 1984. Postharvest Biotechnology of Vegetables. 1st ed. CRC Press, Boca Raton FL.

121. Schwartz, H. F., and Steadman, J. R. 1978. Factors affecting sclerotia populations of, and apothecium production by, Sclerotinia sclerotiorum. Phytopathology 68:383-388.

122. Schwartz, H. F., Steadman, J. R., and Coyne, D. P. 1978. Influence of Phaseolus vulgaris blossoming characteristics and canopy structure upon resistance to Sclerotinia sclerotiorum. Phytopathology 68:465-470.

123. Sesan, T. E., and Crisan, A. 1998. Putregaiul Alb al Plantelor de Cultura Sclerotinia sclerotiorum, Prevenire si Combatere. Editura Ceres, Bucuresti, Romania.

124. Shibairo, S. I., Upadhyaya, M. K., and Toivonen, P. M. A. 1998. Influence of preharvest water stress on postharvest moisture loss of carrots (Daucus carota L.). J. Hortic.
Sci. Biotech. 73:347-352.

125. Shibairo, S. I., Upadhyaya, M. K., and Toivonen, P. M. A. 1998. Potassium nutrition and postharvest moisture loss in carrots (Daucus carota L.). J. Hortic. Sci. Biotech. 78:862-866.

126. Singh, D. 1991. Biocontrol of Sclerotinia sclerotiorum (Lib.) de Bary by Trichoderma harzianum. Trop. Pest Manage. 37:374-378.

127. Smith, A. M. 1972. Biological control of fungal sclerotia in soil. Soil Biol. Biochem. 4:131-134.

128. Steadman, J. R. 1979. Control of plant diseases caused by Sclerotinia species. Phytopathology 69:904-907.

129. Steadman, J. R. 1983. White mold - a serious yield-limiting disease of bean. Plant Dis. 67:346-350

130. Stelfox, D., Williams, J. R., Soehngen, U., and Topping, R. C. 1978. Transport of Sclerotinia sclerotiorum ascospores by rapeseed pollen in Alberta. Plant Dis. Rep. 62:576579.

131. Subbarao, K. V. 2002. Cottony rot/Pink rot. Pages 29-30 in: Compendium of Umbelliferous Crop Diseases. R. M. Davis and R. N. Raid, eds. American Phytopathological Society, St. Paul, MN.

132. Tahvonen, R. 1985. The prevention of Botrytis cinerea and Sclerotinia sclerotiorum on carrots during storage by spraying the tops with fungicide before harvesting. Ann. Agric. Fenn. 24:89-95.

133. Tariq, V.-N., and Jeffries, P. 1987. Cytochemical localization of lipolytic enzyme activity during penetration of host tissues by Sclerotinia sclerotiorum. Physiol. Mol. Plant Pathol. 30:77-91.

134. Tate, K. G. 1980. Sclerotinia in baby carrots. N.Z. Commercial Grower 35:24-25.

135. Teo, B. K., and Morrall, R. A. A. 1985. Influence of matric potentials on carpogenic germination of sclerotia of Sclerotinia sclerotiorum. I. Development of an inclined box technique to observe apothecium production. Can. J. Plant Pathol. 7:359-364.

136. Teo, B. K., Verma, P. R., and Morrall, R. A. A. 1992. The effects of herbicides and mycoparasites at different moisture levels on carpogenic germination in Sclerotinia sclerotiorum. Plant Soil 139:99-108.

137. Tronsmo, A. 1989. Trichoderma harzianum used for biological control of storage rot on carrots. Norw. J. Agric. Sci. 3:157-161.

138. Trutmann, P., Keane, P. J., and Merriman, P. R. 1982. Biological control of Sclerotinia sclerotiorum on aerial parts of plants by the hyperparasite Coniothyrium minitans. Trans. Br. Mycol. Soc. 78:521-529.

139. Tu, J. C. 1984. Mycoparasitism by Coniothyrium minitans on Sclerotinia sclerotiorum and its effect on sclerotial germination. Phytopathol. Z. 109:261-268.

140. Tu, J. C. 1989. Modes of primary infection caused by Sclerotinia sclerotiorum in navy beans. Microbios 57:85-91.

141. Turkington, T. K., Morall, R. A. A., and Gugel, R. K. 1991. Use of petal infestation to forecast stem rot of canola: Evaluation of early bloom sampling, 1985-1990. Can. J. Plant Pathol. 13:50-59.

142. Turkington, T. K., and Morrall, R. A. A. 1993. Use of petal infestation to forecast Sclerotinia stem rot of canola: The influence of inoculum variation over the flowering period and canopy density. Phytopathology 83:682-689.

143. Turner, G. J., and Tribe, H. T. 1976. On Coniothyrium minitans and its parasitism of Sclerotinia species. Trans. Br. Mycol. Soc. 66:97-105.

144. Twengstrom, E., Sigvald, R., Svensson, C., and Yuen, J. 1998. Forecasting Sclerotinia stem rot in spring sown oilseed rape. Crop Prot. 17:405-411.

145. van den Berg, L., and Lentz, C. P. 1966. Effect of temperature, relative humidity and atmospheric composition on changes in quality of carrot during storage. Food Technol. 20:104-107.

146. van den Berg, L., and Yang, S. M. 1969. Effect of relative humidity on production of extracellular pectolytic enzymes by Botrytis cinerea and Sclerotinia sclerotiorum. Can. J. Bot. 47:1007-1010.

147. Waterston, J. M. 1939. Report of the Department of Agriculture for the year 1938. Department of Agriculture and Fisheries, Bermuda.

148. Weiss, A., Hipps, L. E., Blad, B. L., and Steadman, J. R. 1980. Comparison of withincanopy microclimate and white mold disease (Sclerotinia sclerotiorum) development in dry edible beans as influenced by canopy structure and irrigation. Agric. Meteorol. 22:11-21.

149. Whipps, J. M., and Budge, S. P. 1993. Transmission of the mycoparasite Coniothyrium minitans by collembolan Folsomia candida (Collembola: Entomobryidae) and glasshouse sciarid Bradysia sp. (Diptera: Sciaridae). Ann. Appl. Biol. 123:165-171.

150. Willets, H. J., and Wong, A.-L. 1980. The biology of Sclerotinia sclerotiorum, S. trifoliorum, and $S$. minor with emphasis on specific nomenclature. Bot. Rev. 46:101-165.

151. Williams, G. H., and Western, J. H. 1965. The biology of Sclerotinia trifoliorum Erikss. and other species of sclerotium-forming fungi. I. Apothecium formation from sclerotia. Ann. Appl. Biol. 56:253-260.

152. Williams, J. R., and Stelfox, D. 1980. Influence of farming practices in Alberta on germination and apothecium production of sclerotia of Sclerotinia sclerotiorum. Can. J. Plant Pathol. 2:169-172.

153. Williams, J. R., and Stelfox, D. 1980. Occurrence of ascospores of Sclerotinia sclerotiorum in areas of central Alberta. Can. Plant Dis. Surv. 60:51-53. 